Article

\title{
Emerging Urban Forests: Opportunities for Promoting the Wild Side of the Urban Green Infrastructure
}

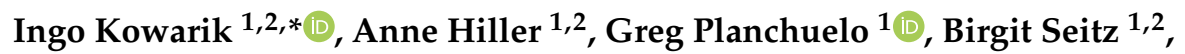 \\ Moritz von der Lippe ${ }^{1,2}$ and Sascha Buchholz ${ }^{1,2}$ \\ 1 Technische Universität Berlin, Department of Ecology, D-12165 Berlin, Germany; \\ anne.hiller@tu-berlin.de (A.H.); greg.planchuelo@gmail.com (G.P.); birgit.seitz@tu-berlin.de (B.S.); \\ moritz.vdlippe@tu-berlin.de (M.v.d.L.); sascha.buchholz@tu-berlin.de (S.B.) \\ 2 Berlin-Brandenburg Institute of Advanced Biodiversity Research (BBIB), D-14195 Berlin, Germany \\ * Correspondence: kowarik@tu-berlin.de; Tel.: +49-3031471350
}

Received: 5 October 2019; Accepted: 7 November 2019; Published: 11 November 2019

\begin{abstract}
Many cities aim to increase urban forest cover to benefit residents through the provision of ecosystem services and to promote biodiversity. As a complement to traditional forest plantings, we address opportunities associated with "emerging urban forests" (i.e., spontaneously developing forests in cities) for urban biodiversity conservation. We quantified the area of successional forests and analyzed the species richness of native and alien plants and of invertebrates (carabid beetles, spiders) in emerging forests dominated by alien or native trees, including Robinia pseudoacacia, Acer platanoides, and Betula pendula. Emerging urban forests were revealed as shared habitats of native and alien species. Native species richness was not profoundly affected by the alien (co-)dominance of the canopy. Instead, native and alien plant species richnesses were positively related. Numbers of endangered plants and invertebrates did not differ between native- and alien-dominated forest patches. Patterns of tree regeneration indicate different successional trajectories for novel forest types. We conclude that these forests (i) provide habitats for native and alien species, including some endangered species, (ii) allow city dwellers to experience wild urban nature, and (iii) support arguments for adapting forests to dynamic urban environments. Integrating emerging urban forests into the urban green infrastructure is a promising pathway to sustainable cities and can complement traditional restoration or greening approaches.
\end{abstract}

Keywords: biodiversity conservation; cemeteries; endangered species; invasive tree species; plant invasions; passive restoration; rewilding; secondary succession; urban woodland; urban wilderness

\section{Introduction}

The pressure on forests around cities is increasing in many parts of the world, with urban growth and intensified land use as key drivers [1-3]. As a consequence, forest patches within cities are of increasing importance for biodiversity conservation $[4,5]$ and are highly valued by urban dwellers due to their contribution to liveable cities and the wealth of associated ecosystem services they bring [6-9]. Complementing the urban green infrastructure with new forests is thus a timely challenge for cities around the globe $[8,10-12]$.

Yet forest patches in cities differ considerably in terms of their origin and the way in which humans have shaped their development $[10,13,14]$ and could thus contribute differently to urban biodiversity conservation. A traditional conservation focus is on natural forest remnants that many cities encompass within their borders, including in tropical $[15,16]$, temperate $[17,18]$, and boreal regions $[19,20]$. Natural 
remnants in cities provide habitats for species of conservation concern [21-24], but have often been lost, transformed or fragmented due to urban development $[5,10,25]$.

Creating new forests by planting trees in cities is well established in restoration ecology, e.g., [26-29], ranging from near-natural sites at the urban fringe, e.g., [30,31], to anthropogenically altered sites [32-34]. Yet such tree plantings and related maintenance require the allocation of considerable resources and do not always yield satisfying results, e.g., when continued maintenance is necessary [31,35]. It may thus be useful to consider complementary pathways towards establishing new forests in cities. We focus here on "emerging urban forests" as forests that evolve on urban sites through natural processes (e.g., colonization, and succession). Generally, emerging forests have been defined as secondary, or successional forests, developing in response to severe disturbance or abandonment of previous land use as illustrated in Figure 1 [36-39].

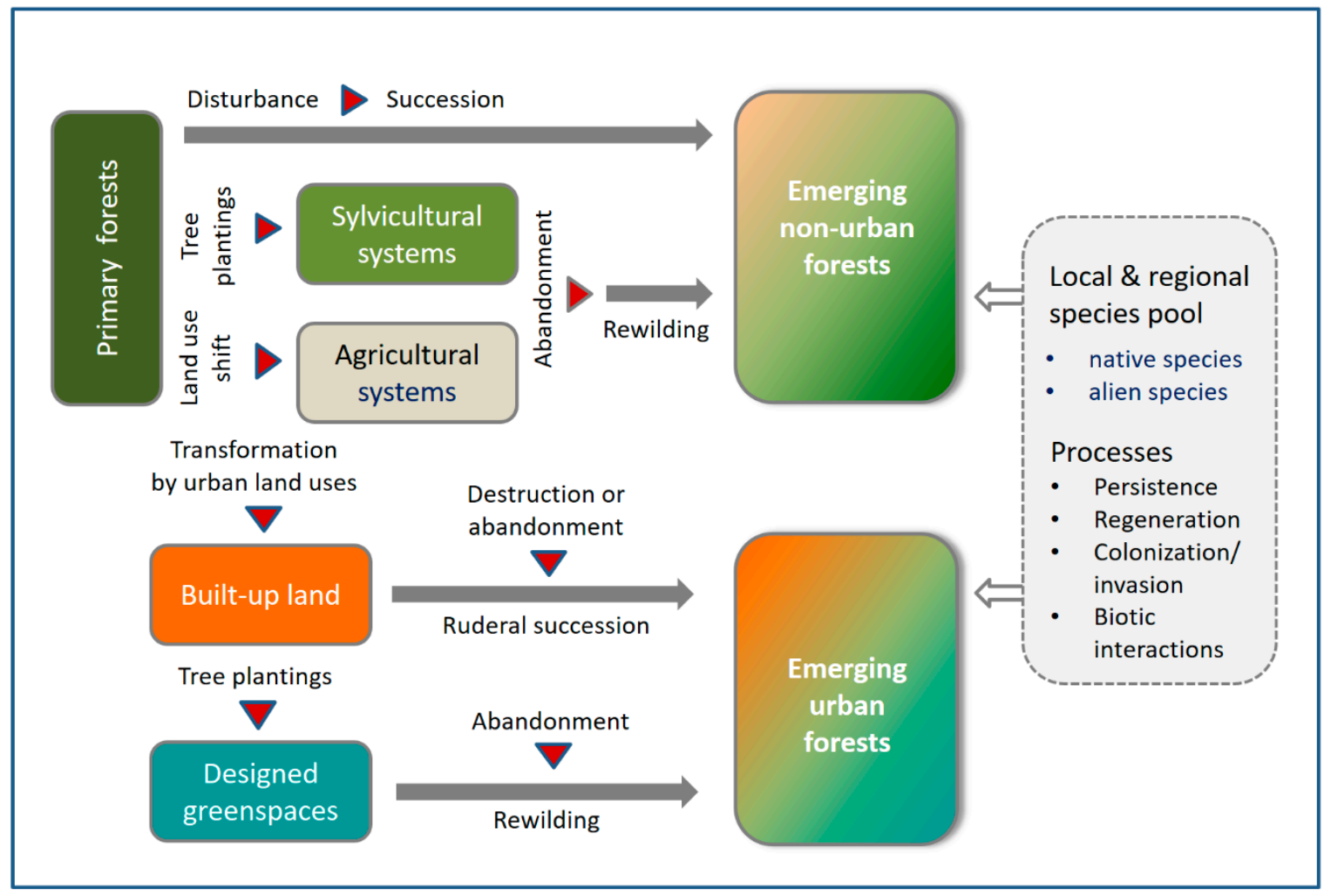

Figure 1. Pathways to emerging forests in non-urban (above) and urban environments (below). Red triangles indicate major drivers of change. Grey arrows illustrate successional processes that may start from either open land subsequent to major disturbance events or abandonment of land-use. Rewilding covers successional processes within a matrix of existing vegetation, in response to a decrease or cessation in management.

In cities, emerging forests can result from different development paths. The first pathway is the colonization of previously cleared or abandoned urban-industrial land, indicated as ruderal succession in Figure 1. Outcomes of ruderal succession series have been reported for a range of urban-industrial land-use types [40-44], including vacant lots [33,45-47], transportation corridors [48,49], post-industrial sites [38,43,50-52], and landfills [53,54]. A second, less acknowledged pathway towards emerging urban forests is spontaneous rewilding of designed greenspaces. This is a parallel to rural landscapes where forests evolve in response to decreased (or ceased) agrarian land use [36,55], sylvicultural management [56,57] (Figure 1), or the abandonment of villages and farmsteads [58,59]. Although rewilding is likely a common process in many urban greenspaces, resulting wild woods have been mostly reported for old cemeteries in Europe, e.g., [60-63]. As an exception, Pregitzer et al. [64] recently reported successional forests in urban parks in New York City. 
We expected that different types of emerging forests in cities harbor different species assemblages due to filtering in terms of divergent seed sources and environmental conditions. While the species composition in successional forests mainly results from colonization from adjacent seed sources, previously planted ornamentals and co-occurring wild species provide additional seed sources in rewilded green spaces. Moreover, succession in rewilded greenspaces starts from developed soils with an increased nutrient availability, whereas ruderal soils have different features, which have been shown to affect biodiversity patterns $[42,48,65]$.

Making use of successional processes is established practice in restoration ecology [66-68] and is often referred to as "passive restoration" [55]. Since the beginning of this century, rewilding has been a hot topic in ecosystem management and biodiversity conservation $[55,69]$ and is also attracting increasing attention in cities $[51,70,71]$. However, since cities are hotspots for alien plant species, there are concerns that introduced species could have a negative impact on native species in urban forest patches $[13,26,27,72-75]$.

Indeed, historical analyses of urban floras have revealed a steep increase in numbers of alien woody species [76-78]. Wild-growing alien species contributed, for example, $16 \%$ to Berlin's woody flora in 1800 but $67 \%$ in 1990 [79]. Remnant forest patches in cities harbor more alien species than in non-urban environments [80], with the higher numbers of alien species due to edge effects [81]. Moreover, alien species can dominate successional forests on urban land as was shown first for Berlin [40,82] and beyond, e.g., [45,83]. Whether emerging urban forests provide habitats for native plant and animal species-despite the generally high occurrence of alien species in cities-is understudied though.

The degree to which alien species are drivers or passengers of change [84] in urban environments likely depends on the characteristics of the dominant species and the particular ecosystem types [85]. Yet there is limited evidence about the role of emerging urban forests in large cities and their domination by native or alien tree species. Moreover, comparative analyses of diversity patterns of different types of successional forests in cities are rare; but see [49,86,87].

Here we analyze biodiversity patterns of emerging urban forests within the city of Berlin, Germany, at two spatial scales. At the city scale, we quantified the area of successional forests on open land (i.e., outside designed greenspaces) and the dominant tree species. Given the high propagule pressure of introduced woody species as a typical urban feature [79,88-90], we expected that most of these forest patches would be dominated by alien tree species.

At the community scale, we analyzed how the alien vs. native status of dominant tree species related to diversity patterns of plants and invertebrates in the ground layer. Our data set included (i) successional forests on previously open land and (ii) rewilded tree stands on old cemeteries. The latter are a prominent example of rewilded urban greenspace and are increasingly important in European cities due to changing burial practices [91]. As a consequence, parts of many cemeteries in Berlin are no longer used for burials, and natural processes have been allowed to proceed with limited management interference.

We hypothesized a negative relationship between native species richness in the ground layer and alien dominance in the canopy and thus expected native species richness to decrease from (i) plots dominated by a common native tree species (Betula pendula; [92]) to (ii) plots covered by a mixture of native and alien tree species (native Acer platanoides, alien A. pseudoplatanus; [93]) to (iii) plots dominated by Robinia pseudoacacia, a North American tree species that modifies associated plant assemblages due to nitrogen fixation $[94,95]$.

We adopted a multi-taxon approach to compare responses of vascular plants and two groups of invertebrates (carabid beetles and spiders) to the dominant tree species because (i) different groups of taxa perform differently in early stages of forest succession [96] and (ii) alien dominance in plant species might affect higher trophic levels if introduced species provide less suitable resources for animal species $[97,98]$. Since endangered species are important indicators of the conservation value of habitats, we tested whether their number differed across forest types. 
In detail, we addressed two main research questions at the landscape scale: (1) how important are successional forests that have emerged on previously open land in Berlin (in terms of total area, patch number, patch size)? and (2) to what extent are these forests dominated by native or alien tree species or a mixture of the two?

Addressing the community scale, we further asked: (3) do emerging urban forests that are dominated by native vs. alien tree species differ (a) in terms of plant and invertebrate richness (total, alien, native species, and endangered species), and (b) in the composition of their species assemblages? and (4) is the number of alien plant species in the ground and shrub layers of emerging urban forests negatively related to native plant species richness?

\section{Methods}

\subsection{Study Region and Study System}

Berlin is Germany's largest city with 3.6 million inhabitants within a total area of $891.1 \mathrm{~km}^{2}$. While $48 \%$ of the land within the administrative borders of the city is built-up areas and another $10.9 \%$ streets, $41.1 \%$ of the city is represented by green or blue spaces. These include forests $(17.5 \%)$, lakes and rivers (6\%), parks and other greenspaces [99].

Natural forest remnants on the prevailing sandy soils are dominated by oaks (Quercus robur, Q. petraea) and Scots pine (Pinus sylvestris), but many of these stands have been replaced by intensively managed plantations; forest remnants on wet soils are dominated by alder (Alnus glutinosa [82]). Important native pioneer trees are Betula pendula, Populus tremula, Salix caprea, and Sorbus aucuparia [100], which are abundant on forest sites and also on vacant urban land [41,79]. The most frequent non-native tree species in Berlin include Robinia pseudoacacia, Prunus serotina, Acer negundo, Quercus rubra, and Ailanthus altissima [79]. Two maple species (Acer platanoides, A. pseudoplatanus) were rare in Berlin up to the end of the 19th century, but are among the most abundant tree species today due to frequent plantings in forests, urban greenspaces, and along streets [101]. While A. platanoides is considered native to Berlin, A. pseudoplatanus is listed as an alien species [93].

Due to destruction during World War II and delayed urban development until the German reunification in 1989, a considerable amount of vacant land remained within the city and was recolonized through natural succession. At the beginning of the 1980s, 142 sites of spontaneously vegetated vacant land with a total area of 550 ha and covering $1.2 \%$ of the total area of (then West) Berlin had been mapped as "Stadtbrachen" [102]. While some of these areas remained as wild urban woodland, others were integrated into urban parks or were re-built as Berlin began growing again [103-105].

Forest succession on vacant land in Berlin has been described since the 1960s, based on field studies (synthesis by $[40,54,82]$ ) and experimental studies [106,107]. A few studies have analyzed invertebrates in successional forests on vacant land [108,109] and on a rewilded cemetery [62].

Cemeteries in Berlin are appropriate models for studying successional processes in tree-dominated greenspaces as most have been designed in a park style, with tree allées, tree clumps, and individual trees. Berlin has 220 cemeteries within its administrative borders, covering 1125 ha in total [99]. In a pioneer study, Graf [110] reported 690 wild-growing plant species from 42 cemeteries with a total size of 297 ha; $13.5 \%$ were tree species. Due to changes in burial practices, a considerable amount of Berlin's cemeteries are not used anymore, resulting in significantly decreased management or abandonment. Therefore, 290 ha (28\%) of Berlin's cemetery area are planned to be converted to public green spaces or some other use.

Most of the wild parts of cemeteries are dominated by A. platanoides, A. pseudoplatanus, or a combination of the two maple species, as demonstrated in studies of the Jewish cemetery in Weißensee [62,109] and in other greenspaces [111,112]. 


\subsection{Analyses at the Landscape Scale}

To respond to the first research question, we used the biotope map of Berlin [99] to determine the dominant tree species of the successional forest patches that have emerged on open land within Berlin (i.e., outside formal greenspaces and forest areas). We differentiated among forest patches dominated by the following species: Betula pendula, Populus tremula, Robinia pseudoacacia, Populus $\times$ canadensis, Acer spp. as well as an additional category ("other") when there was no data about the dominant species (Figure 2). This selection of species corresponds to the differentiation of biotope types in Berlin's biotope map. For each type of successional forest, we calculated patch number and size with the field calculator in QGIS [113].

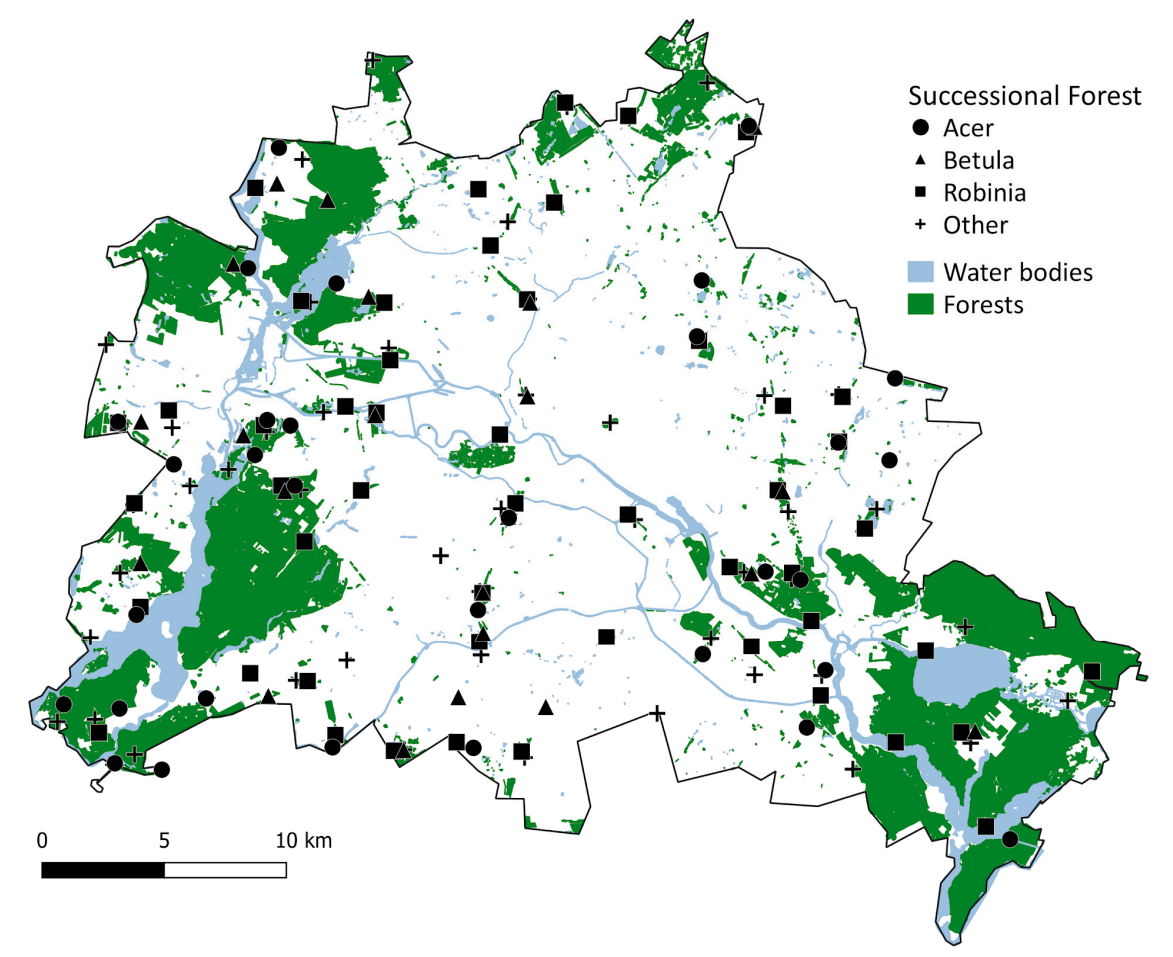

Figure 2. Locations of 516 patches of successional forests in Berlin, based on Berlin's biotope map [99], that were analyzed at the landscape scale. The symbols indicate different forest types, dominated by different tree species according to Berlin's biotope map. The number of visible symbols is lower than total patch number due to overlapping symbols. Please note that rewilded forests in greenspaces are not shown here.

\subsection{Analyses at the Community Scale}

To respond to the second research question of whether the patches were dominated by native species, alien species, or a combination of the two, we compared species assemblages of three types of emerging forests that are all common in Berlin: (i) native B. pendula stands, (ii) Acer stands that are dominated by the native A. platanoides or the alien A. pseudoplatanus or a mixture of both, and (iii) stands of the alien R. pseudoacacia.

We used data from a plot-based sampling of the three forest types for vascular plants and two groups of ground-dwelling arthropods (carabid beetles, spiders; see Table 1 for details on data sources). While vascular plants are a standard group in urban biodiversity studies [114], the two less commonly studied invertebrate groups are suitable indicator species due to pronounced habitat preferences in urban habitats in general (e.g., [115-117]) and urban forests in particular (e.g., [118]).

All vascular plant species were recorded in 119 plots, each $10 \mathrm{~m} \times 10 \mathrm{~m}$, which were distributed across Berlin (Figure 3). For the Acer-dominated forest type, we analyzed 30 plots from wild parts of ten Christian cemeteries. We further included data from 21 plots that had been sampled in rewilded parts 
of a large (39 ha) 19th-century Jewish cemetery [62,109]. For stands dominated either by B. pendula or $R$. pseudoacacia we re-analyzed data from a previous study [49]. In this study, 34 pairs of woodland patches had been selected based on the biotope map of Berlin, with one patch dominated by B. pendula and the other by R. pseudoacacia. These pairs were separated by at least $1000 \mathrm{~m}$ to avoid spatial autocorrelation. Within each patch of the woodland pairs, a study plot was randomly located. A minimum distance of $20 \mathrm{~m}$ was kept between plots to avoid neighboring effects.

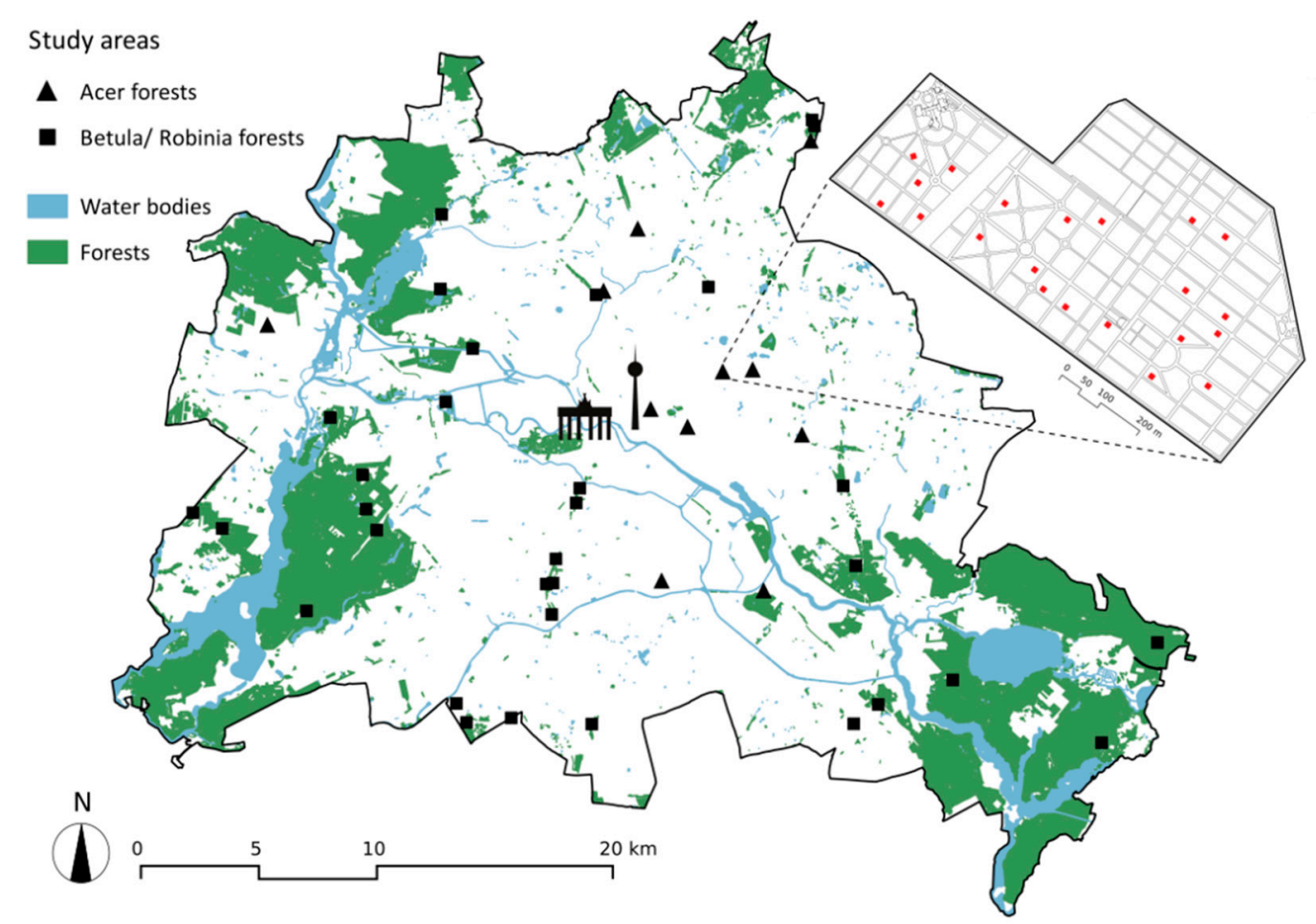

Figure 3. Location of the forest patches within Berlin that were analyzed at the community scale. Triangles represent Acer forests on rewilded cemeteries, and squares represent Betula and Robinia forest patches, resulting from ruderal succession. Water bodies are shown in blue and forest areas in green. One area, the Weißensee Jewish cemetery, is shown at a larger scale to illustrate the distribution of the $10 \mathrm{~m} \times 10 \mathrm{~m}$ plots (red squares) for vegetation and invertebrate sampling. The icons indicate the city center of Berlin.

The vegetation data were stored and tabulated with the software TURBOVEG for Windows [119]. The differentiation between native and non-native species followed [93]. The group of native species was merged with the group of archaeophytes (pre-1492 introductions), while the group of non-native species included neophytes (post-1492 introductions).

For carabid beetles and spiders, we used data from 41 plots that were a subset of the vegetation plots (Table 1). For the Acer stands, we analyzed data from the Jewish cemetery [62,109]. For Betula and Robinia stands, we re-analyzed data from [87], who had sampled invertebrates in a set of ten woodland pairs. For each pair, one patch was dominated by B. pendula and the other by R. pseudoacacia (more than $90 \%$ coverage each). Both taxa were sampled using three uncovered and randomly installed pitfall traps keeping a minimum distance of $5 \mathrm{~m}$ between them. Pitfall traps were $500 \mathrm{~mL}$ white plastic cups ( $9 \mathrm{~cm}$ diameter, $12 \mathrm{~cm}$ depth) filled with a $4 \%$ formalin-detergent solution $(125 \mathrm{~mL})$. Both sampling periods lasted two months, and emptying was done twice at four- week intervals. Finally, we identified carabid beetles and spiders to species level using standard determination keys for carabids [120] and spiders [121-123]. In contrast to vascular plants, carabid beetles and spiders were not assigned to either natives or non-natives since the percentage of non-native species in both groups is very low in Berlin $[124,125]$. 
As species of conservation concern, we addressed endangered species listed in the regional Red Lists for Berlin for plants [126], spiders [125] and carabids [124].

Table 1. Information about study areas, plots, and sampling methods for vascular plants and invertebrates (carabid beetles and spiders) for forests dominated by Acer, Robinia or Betula.

\begin{tabular}{|c|c|c|c|}
\hline Vascular Plants & \multicolumn{2}{|c|}{ Acer Forests } & $\begin{array}{c}\text { Betula and Robinia } \\
\text { Forests }\end{array}$ \\
\hline Study area & $\begin{array}{l}\text { Weißensee Jewish } \\
\text { cemetery }\end{array}$ & 10 Christian cemeteries & $\begin{array}{l}\text { Successional forests } \\
\text { across Berlin }\end{array}$ \\
\hline Data source & {$[62,109]$} & This study & {$[49]$} \\
\hline Number of plots & 21 & 30 & $\begin{array}{c}\text { Paired plots, } 34 \\
\text { dominated by Betula } \\
\text { pendula, } 34 \text { dominated by } \\
\text { Robinia pseudacacia ( } 68 \text { in } \\
\text { total) }\end{array}$ \\
\hline Plot size & $10 \mathrm{~m} \times 10 \mathrm{~m}$ & $10 \mathrm{~m} \times 10 \mathrm{~m}$ & $10 \mathrm{~m} \times 10 \mathrm{~m}$ \\
\hline Plot selection & $\begin{array}{l}\text { Random selection with } \\
\text { Hawth's Analysis Tools } \\
\text { for ArcGis }\end{array}$ & $\begin{array}{l}\text { Random selection with } \\
\text { Hawth's Analysis Tools } \\
\text { for ArcGis and Random } \\
\text { Points tool in QGIS }\end{array}$ & Random selection \\
\hline Recording time & April-May 2013 & $\begin{array}{l}\text { April-May 2013; } \\
\text { May-June } 2015\end{array}$ & May-July 2010 \\
\hline $\begin{array}{l}\text { Abundance estimation } \\
\text { method }\end{array}$ & $\begin{array}{l}\text { [127] } \\
\text { transformation of values } \\
\text { into percentages for } \\
\text { statistical analyses }\end{array}$ & $\begin{array}{c}{[127]} \\
\text { transformation of values } \\
\text { into percentages for } \\
\text { statistical analyses }\end{array}$ & $\begin{array}{l}\text { [128] } \\
\text { transformation of values } \\
\text { into percentages for } \\
\text { statistical analyses }\end{array}$ \\
\hline \multicolumn{4}{|l|}{ Invertebrates } \\
\hline Study area & $\begin{array}{l}\text { Weißensee Jewish } \\
\text { cemetery }\end{array}$ & & $\begin{array}{l}\text { Successional forests } \\
\text { across Berlin }\end{array}$ \\
\hline Data source & {$[62,109]$} & & {$[87]$} \\
\hline Number of plots & 21 & & 20 \\
\hline Recording time & 24 April-25 June 2013 & & 1 May-30 June 2012 \\
\hline
\end{tabular}

\subsection{Statistical Analyses}

\subsubsection{Landscape Scale}

We tested for differences in the patch sizes among Betula, Acer, and Robinia forests by means of a Kruskal-Wallis rank sum test with the package 'stats' in R 3.4.4 (R Foundation for Statistical Computing. Vienna, Austria) [129]. This is a non-parametric analysis that tests the null hypothesis that two or more samples from a dependent variable belong to the same distribution [130]. We used the size of the different forest patches as the dependent variable and the type of forest as the independent variable to test the validity of the null hypothesis that all forests have similar patch sizes.

\subsubsection{Community Scale}

We tested differences in species richness and number of species of conservation concern among the three forest types for vascular plants and invertebrates (summed data from three pitfall traps and carabid beetles and spiders). Differences in origin (native vs. non-native) were tested only for vascular plants. Prior to statistical analysis, normal distribution of data and homogeneity of variance were checked using Shapiro-Wilk and Fligner-Killeen tests. If normal distribution and homogeneity of variance were not met, data were log-transformed. Afterwards, we tested for differences using a one-way ANOVA, and pairwise comparisons were made with Holm-Sidak post-hoc tests. 
To analyze community structure of vascular plants, carabid beetles, and spiders, we ran non-metric multidimensional scaling (NMDS) using the VEGAN package [131]. Before analyses, the relative abundances of 28 carabid, 63 spider, and 148 vascular plant species were square-root transformed. NMDS is an iterative ordination method that places samples in a k-dimensional space using the ranked distances among them. The scaling was based on the Bray-Curtis dissimilarity matrix of taxa. In search of a stable solution for a three-dimensional model, 100 random starts were used. To test if woodland type (Acer, Betula, and Robinia) and woodland origin (rewilded and successional) affected species compositions of vascular plants and invertebrates, we performed a permutational multivariate ANOVA (command 'adonis' in R package 'vegan') with 10,000 permutations.

The relationship between number of neophytes and number of native plant species was tested using linear regression analysis for each forest type after checking for normality of data distribution using the Shapiro-Wilk test.

All statistical analyses were performed using the software environment R 3.4.4 (R Foundation for Statistical Computing. Vienna, Austria) [129].

\section{Results}

\subsection{Successional Forests at the Landscape Scale}

Analyzing the biotope map of Berlin revealed 516 patches of successional forests, with a total area of 337.6 ha (Table 2). About 39\% of patches were clearly dominated by alien tree species, and most of these by R. pseudoacacia. Sixteen percent of forest patches were dominated by native tree species, most prominently by Betula pendula. For a large group of patches $(44 \%)$, the database did not allow the identification of dominant native or non-native tree species. About a third of these patches were dominated by trees of the genus Acer, thus including both native (A. platanoides) and alien (A. pseudoplatanus and A. negundo) species. The size of Betula, Acer, and Robinia forest patches did not differ significantly ( $p=0.49$, Kruskal-Wallis rank sum test).

Table 2. Successional forests emerging on open land in Berlin. Patch number, average patch size, and total area are given for forests dominated by native or alien tree species. The category "undefined" includes mixed native/alien Acer forests and other forest patches that had not been further specified in Berlin's biotope mapping.

\begin{tabular}{cccc}
\hline Dominant Trees & Patch Number & Average Patch Size (ha) & Total Area (ha) \\
\hline Native species & & & \\
Betula pendula & $64(12.4 \%)$ & 0.4536 & $29.0(8.6 \%)$ \\
Populus tremula & $20(3.9 \%)$ & 0.2778 & $5.6(1.7 \%)$ \\
Total native & $84(16.3 \%)$ & 0.4118 & $34.6(10.3 \%)$ \\
\hline Alien species & & & \\
Robinia pseudoacacia & $173(33.5 \%)$ & 0.5842 & $101.1(29.9 \%)$ \\
Populus $\times$ canadensis & $30(5.8 \%)$ & 0.3656 & $11.0(3.3 \%)$ \\
Total alien & $203(39.3 \%)$ & 0.5518 & $112.0(33.2 \%)$ \\
\hline Undefined & & & \\
Acer spp. & $78(15.1 \%)$ & 0.6229 & $48.6(14.4 \%)$ \\
Other species & $151(29.3 \%)$ & 0.9430 & $142.4(42.2 \%)$ \\
Total undefined & $229(44.4 \%)$ & 0.8340 & $191.0(56.6 \%)$ \\
\hline Total & $516(100 \%)$ & 0.6543 & $337.6(100 \%)$ \\
\hline
\end{tabular}

\subsection{Biodiversity Patterns at the Community Scale}

\subsubsection{Biodiversity Measures across Forest Types}

Numbers of plant species differed significantly among the three forest types $(\mathrm{F}=32.72, p<0.001$, one-way ANOVA) (Figure 4). Betula forests had more species compared to Robinia and Acer forests 
(Figure 3). Numbers of plant species of conservation concern did not differ significantly among forest types. However, because of a generally low frequency of these species in all forest types, this diversity measure varied greatly between stands due to a large number of zero values. Therefore, non-significant differences between the forest types may predominantly be attributed to this variation. Percentage of neophytes was significantly higher in Acer forests, while Betula and Robinia forests harbored the same percentage of neophytes ( $\mathrm{F}=7.64, p<0.001$, one-way ANOVA). Consequently, Acer forests had the lowest percentage of natives ( $\mathrm{F}=10.05, p<0.001$, one-way ANOVA). Numbers of invertebrate species and of species of conservation concern did not differ significantly among forest types.
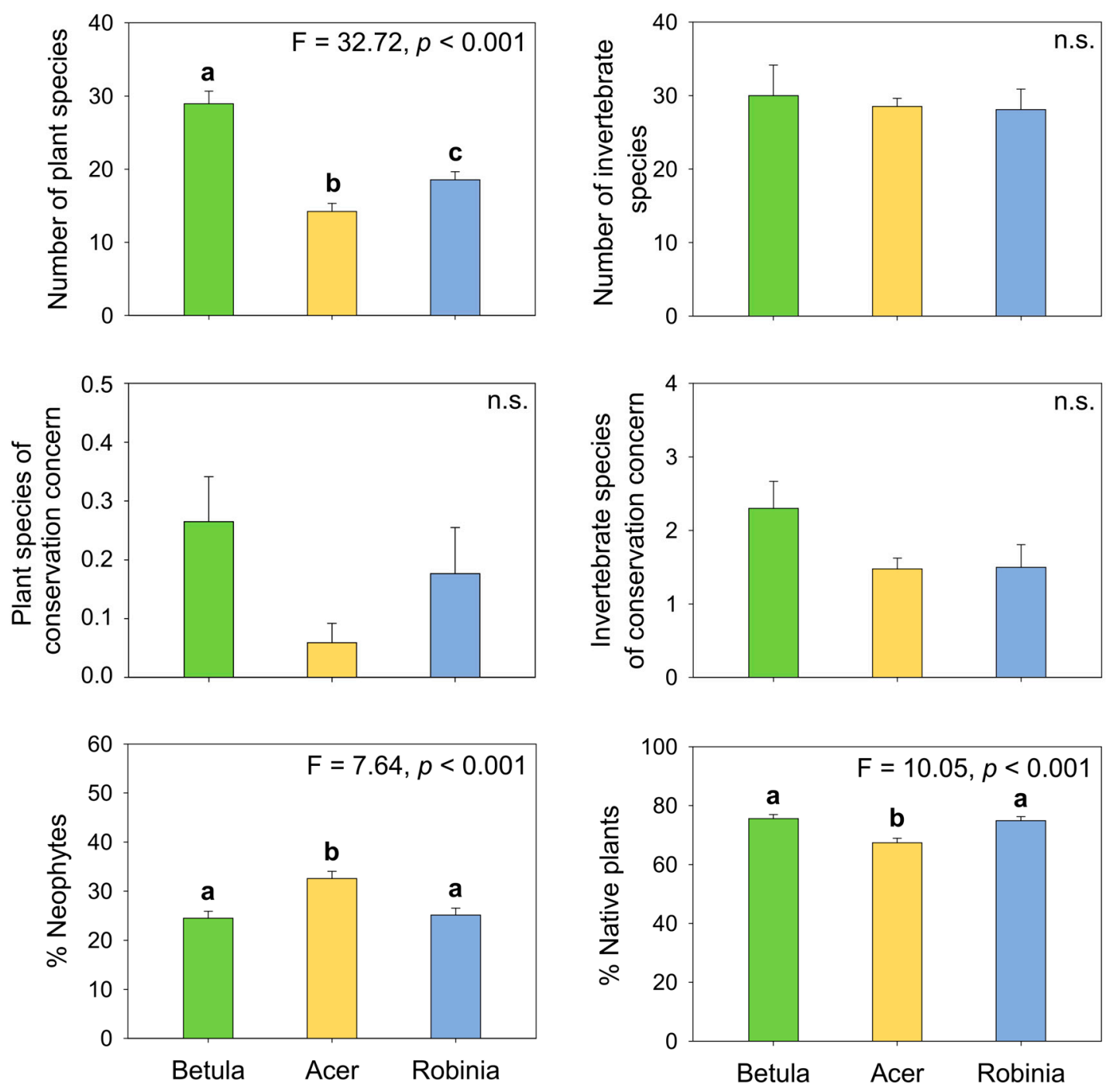

Figure 4. Differences in the mean number of plant species per plot were significant among the three forest types ( $\mathrm{F}=32.72, p<0.001$, one-way ANOVA), whereas number of invertebrates as well as number of species of conservation concern (i.e., red-listed species) did not differ. Percentage of neophytes ( $\mathrm{F}=7.64, p<0.001$, one-way ANOVA) and natives ( $\mathrm{F}=10.05, p<0.001$, one-way ANOVA) differed significantly among forest types with Acer forests showing the highest percentage of neophytes and the lowest percentage of natives. Small letters indicate results of Holm-Sidak post-hoc tests $(p<0.05)$ with different letters indicating significant differences in pairwise comparisons.

A total of 45 tree species were able to colonize the emerging forests (Figure 5), including-combined for the ground and shrub layers-18 native and 27 alien tree species. Tree species richness was similar in the two layers, both for native species (17-18 species) and for alien species (21-23), with some 
differences among forest types (see pie charts in Figure 5). The ground layer of the alien Robinia forest patches, for example, harbored a higher share of native tree species than the native Betula forests.
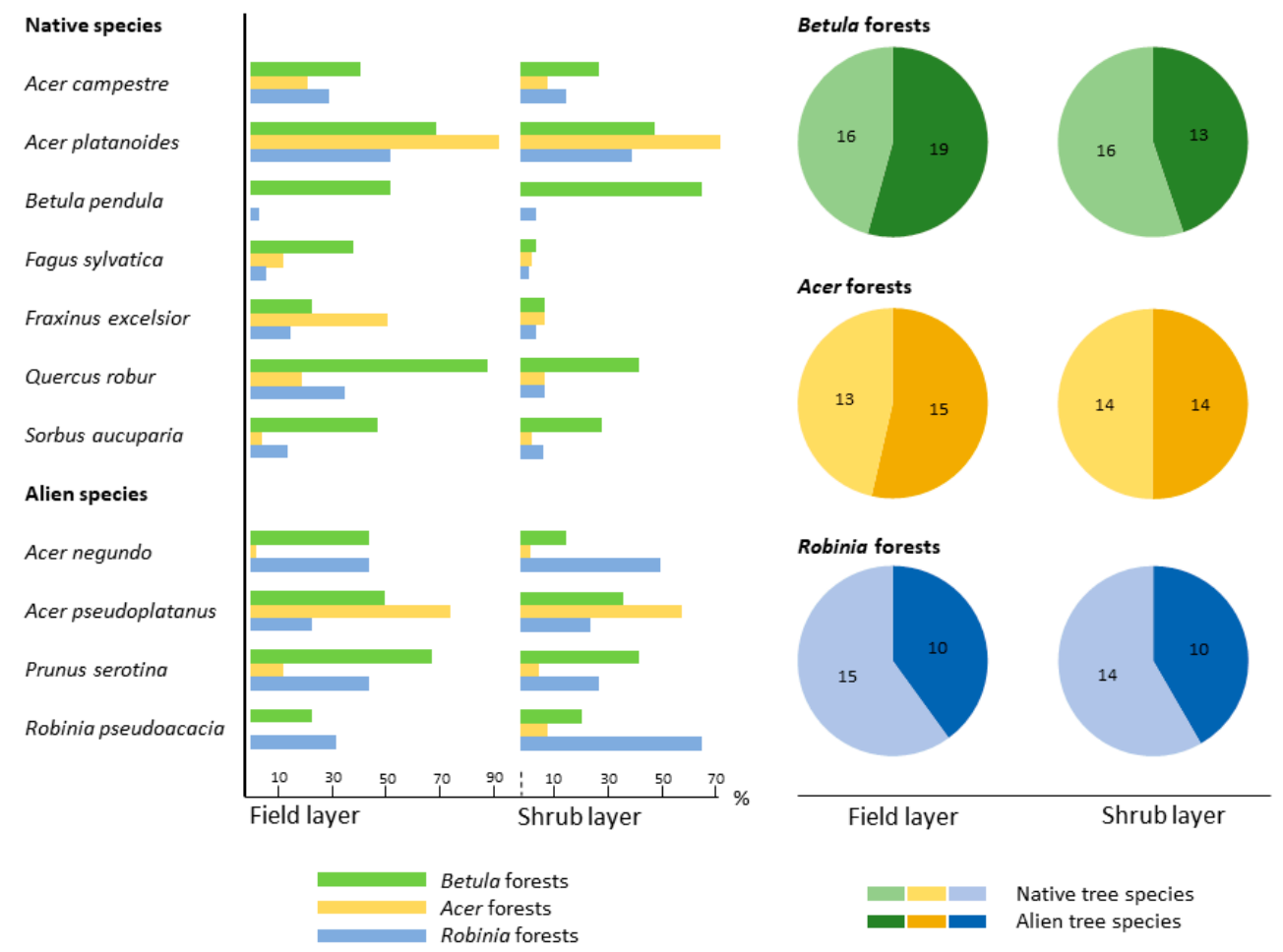

Figure 5. Colonization of the ground and shrub layer of three types of emerging urban forests by native and alien tree species. The pie charts show the total numbers of alien (darker colors) and native (lighter colors) tree species in the ground and shrub layer of each forest type. The columns illustrate the percentage of plots of each forest type in which the given species was found in the ground layer or the shrub layer. Species with a frequency of $>30 \%$ in at least one forest type are shown (Betula: $n=34$ plots, Acer: $n=51$, Robinia: $n=34$ ).

\subsubsection{Species Assemblages across Forest Types}

The NMDS revealed that all three forest types harbored distinct vascular plant species communities (Figure 6), and consequently the permutational MANOVA showed that species distribution was affected by forest type $\left(\mathrm{F}=18.0, \mathrm{df}=2, \mathrm{R}^{2}=0.24, p<0.001\right)$ and forest origin $\left(\mathrm{F}=33.9, \mathrm{df}=1, \mathrm{R}^{2}=0.22\right.$, $p<0.001)$. Regarding invertebrates, similar patterns and effects could be detected although species compositions of Betula and Robinia forests were more similar, and Acer forests were clearly distinct. Both forest type $\left(\mathrm{F}=12.4, \mathrm{df}=2, \mathrm{R}^{2}=0.40, p<0.001\right)$ and forest origin $\left(\mathrm{F}=23.0 \mathrm{df}=1, \mathrm{R}^{2}=0.37\right.$, $p<0.001)$ again significantly affected species distribution of carabid beetles and spiders. 

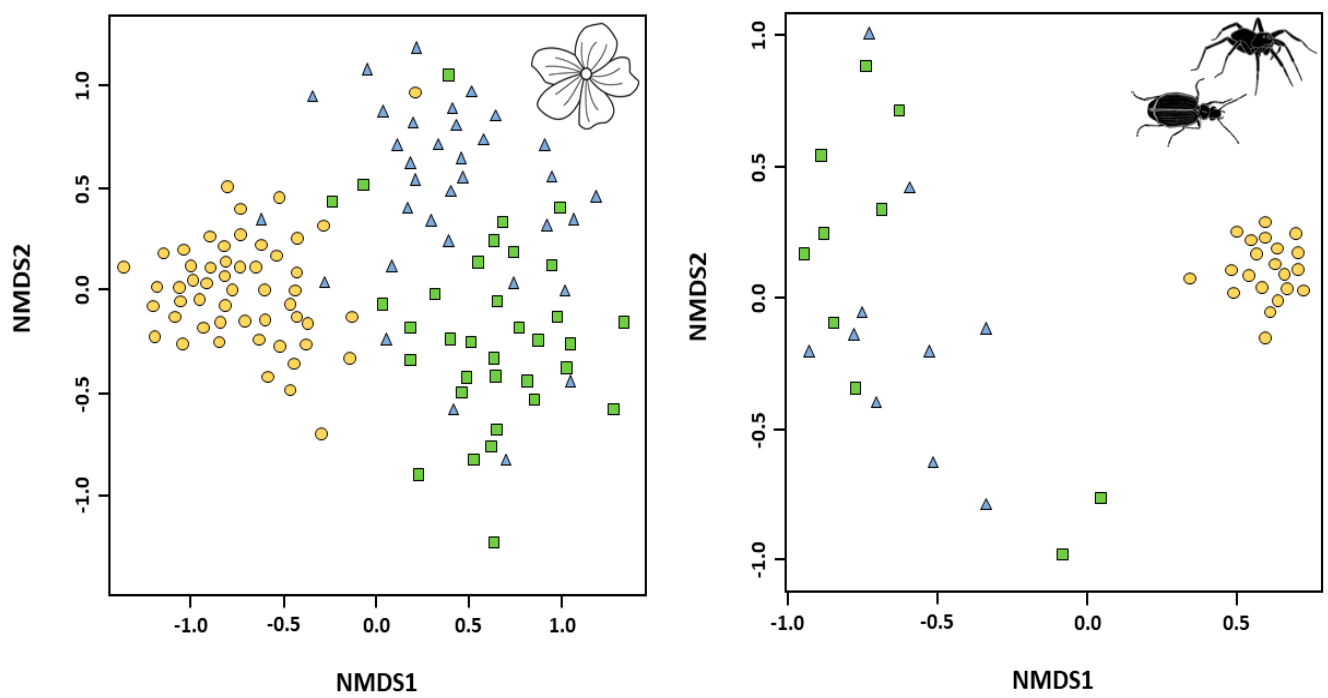

Figure 6. Community structure of emerging urban forests in Berlin for plant species (left) and invertebrates (spiders and carabid beetles; right). Graphical representation of the non-metric multidimensional scaling (NMDS; explanations: green square = Betula forest, yellow circle = Acer forest, and blue triangle $=$ Robinia forest). Species composition of vascular plants (dimensions $=3$, stress $=0.17$ ) was significantly affected by forest type $\left(\mathrm{F}=18.0, \mathrm{df}=2, R^{2}=0.24, p<0.001\right.$, permutational multivariate analysis of variance) and forest origin $\left(\mathrm{F}=33.9, \mathrm{df}=1, R^{2}=0.22, p<0.001\right)$, which was also true for species composition of invertebrates (dimensions $=3$, stress $=0.10$ ) (forest type: $\mathrm{F}=12.4, \mathrm{df}=2$, $R^{2}=0.40, p<0.001$; forest origin: $\left.\mathrm{F}=23.0 \mathrm{df}=1, R^{2}=0.37, p<0.001\right)$.

\subsubsection{Relation between Native and Alien Plant Richness}

Numbers of neophytes significantly increased with increasing number of native plants in all forest types (Figure 7), with the steepest rise of neophytes in Betula forests $(\mathrm{t}=3.3, p=0.002)$ compared to Acer $(\mathrm{t}=8.8, p<0.001)$ and Robinia $(\mathrm{t}=2.4, p=0.02)$ stands.

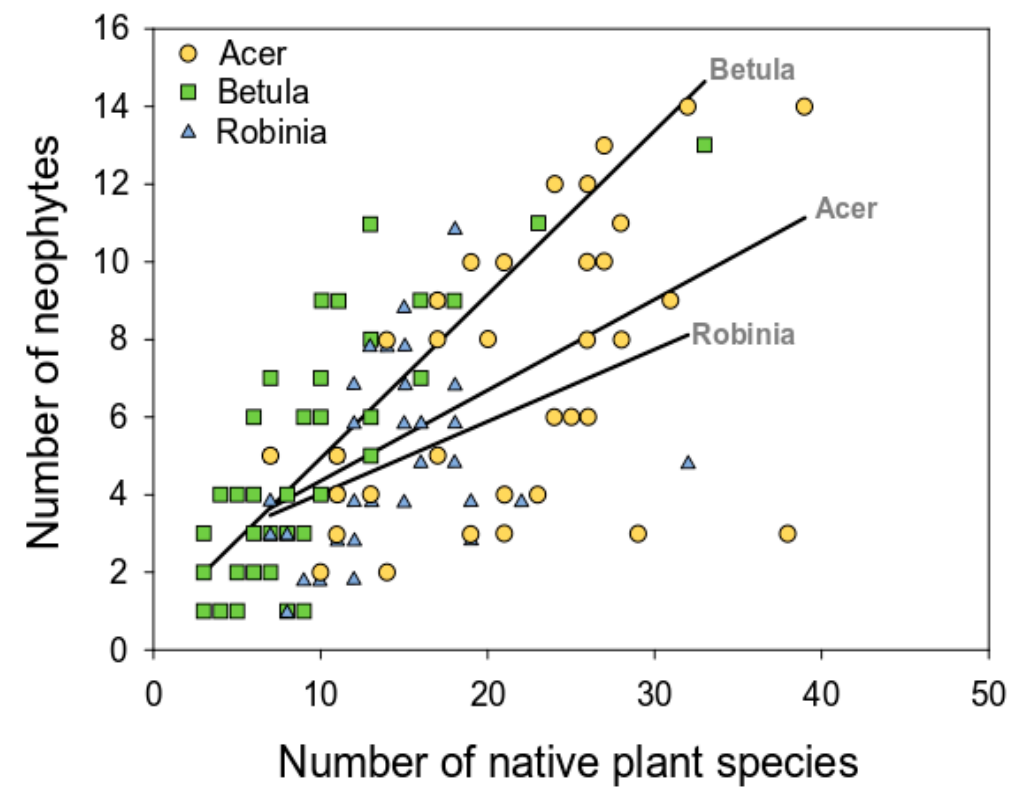

Figure 7. Positive relationship between richness in alien plant species (neophytes) and native plant species in three types of urban emerging forests; linear regression for Betula forests $(\mathrm{t}=3.3, p=0.002)$, Acer forests $(\mathrm{t}=8.8, p<0.001)$, and Robinia forests $(\mathrm{t}=2.4, p=0.02)$. 


\section{Discussion}

Novel urban environments such as vacant lots, abandoned industrial areas, and transportation corridors have increasingly received attention as habitats of plant and animal species, with many studies focused on early or intermediate succession stages [42,132,133]. Here we addressed emerging urban forests as tree-dominated vegetation that could result from different processes such as ruderal succession on previously open urban land or rewilding of greenspaces. While the importance of spontaneously regenerating alien tree species in urban environments is well known, e.g., $[12,13,79,83,88]$, this is likely the first study that unravels how the dominance of alien compared to native tree species in the canopy of wild forest patches relates to biodiversity patterns of multiple taxonomic groups. We were further able to relate the responses of species of conservation concern to the different forest types since Red Lists of endangered plants, spiders, and carabids were available for Berlin.

In the following, we discussed our results on (i) the alien vs. native dominance of successional urban forests at the landscape scale and (ii) biodiversity patterns at the community scale for three types of emerging forests, and (iii) draw conclusions on the role of emerging forests for developing the urban green infrastructure.

\subsection{Successional Forests at the Landscape Scale}

Our study indicates that the emergence of successional forests by "passive restoration" [55], i.e., self-organized community assembly, makes a notable contribution to Berlin's green infrastructure. Our analyses revealed that the total area of successional forests in Berlin (338 ha) was greater than the area covered by Berlin's central park, the Tiergarten (210 ha). Moreover, the high number of 516 forest patches and their dispersion throughout the city (Figure 2) were expected to support ecosystems services and access to wild urban nature also in areas that lack a sufficient provision of formal green spaces.

We expected an alien dominance of successional forests in Berlin as the propagule pressure resulting from extensive plantings of non-native trees in urban environments is a well-established predictor of biological invasions $[134,135]$. This hypothesis was only partially confirmed by our analyses. Forest patches dominated by a single alien tree species indeed made up a larger share than native-dominated patches, but by no means exclusively. A considerable number of patches were also dominated by native trees. The highest number of forest patches, however, was the "undefined" category, which could not be divided into native or alien species due to methodological constraints (i.e., missing differentiation in the Berlin Biotope Map). This impedes a final assessment of the quantitative significance of native vs. alien tree species as both groups are represented by the Acer forest type and in the "other" category. Previous studies revealed Acer forests as dominated by the native $A$. platanoides, alien congeners (A. pseudoplatanus and A. negundo), or mixtures of these species [101,111,112]. Other dominant tree species of successional forests in Berlin include native Salix and Populus species [54] and the alien Ailanthus altissima [136].

The most important successional forest types dominated by a single species were alien Robinia and native Betula forests. Communities of these species have been described since the 1960s for Berlin and beyond [94,95], starting with studies on early successional stages on post-war rubble soils [137] and later covering a broader range of sites, e.g., within transportation corridors (see early synthesis in $[40,82]$. While many previous studies on urban successional forests largely relied on measures of abundance, e.g., $[45,79,138]$, but see $[46,64]$, our analysis adds insights into the relative importance of different tree species as dominants of successional forests in terms of covered area at the city scale.

Stands of the most important alien tree species, R. pseudoacacia, accounted for about three times the area of the most important native tree species, B. pendula. However, patch size-which is important for a range of habitat functions for plants [139] and animals [140]—did not differ significantly among forest types.

Comparing results from Berlin with other studies on successional forests suggests that cities in different biogeographic regions share some dominant tree species, including A. platanoides, 
R. pseudoacacia, and A. altissima, as shown for a Mediterranean city [45] and for temperate North American cities $[13,46,64,83]$. Whether the shared dominance of the same tree species in different cities will lead to a biotic homogenization of urban successional forests deserves further comparative studies on a global scale.

\subsection{Biodiversity Patterns at the Community Scale}

Our multi-taxonomic study demonstrated clear differences in species assemblages of forest types but did not consistently confirm the expected negative relationship between alien tree dominance and (native) species richness across plant and invertebrate species (Figure 4). The current species assemblages as well as the future development of the forests, indicated by tree recruitment patterns, suggest emerging urban forests in Berlin as novel forest types and shared habitats of native and alien species.

\subsubsection{Total, Native, and Alien Richness}

Cities are hotspots of alien species, and this phenomenon has been addressed in very different ways: as a threat to native biodiversity, e.g., [75] or as a sign of adaptation to novel urban conditions, e.g., [141]. Since the dominance of alien trees in the canopy of emerging urban forests decreased from Robinia to Acer to Betula forests, we could test for related effects on the total, native, and alien species richness, and on the community structure of the three forest types.

For invertebrates, species richness did not differ significantly among forest types. As there were no alien spider or carabid species in our study, results demonstrate the absence of negative effects of a dominant alien - and invasive - tree species (i.e., Robinia) on native invertebrates. This adds evidence to neutral effects of invasive plants on animal species, which has been demonstrated before for spiders. In a previous insect study, however, negative effects prevailed [97], likely due to the inclusion of herbivorous insects that usually rely more on resources of native plant species than do other functional groups [97], but see [142].

For plants, patches of the native Betula pendula showed the highest total species richness, while stands of the alien Robinia harbored significantly fewer plant species, as shown previously [49]. It is likely that the capacity of Robinia to increase nitrogen availability for associated species $[94,143]$ promotes a less diverse suite of competitive, N-demanding ruderal species [94,144], resulting in a lower plant species richness in the understory compared to native Betula stands [49].

Surprisingly, the mixed native/alien Acer forests had significantly fewer plant species in total and more alien species than both the alien Robinia and the native Betula stands. The lower species richness is likely an effect of resource availability as light is usually limited in the ground layer of Acer stands, resulting in a limited number of shade-tolerant species in the understory [138]. Correspondingly in its alien range in North America, stands of A. platanoides had fewer plant species than native forest communities [145]. The higher numbers of alien species in the Acer forests in this study can be explained by their emergence in rewilded greenspaces. Here, community assembly descends not only from colonization from adjacent seed sources-as in the other successional forests-but also involves previously planted ornamentals and extant wild species. In fact, escaped ornamentals play an important role in the flora of cemeteries, as shown for Berlin [62,110], and correspondingly in Acer forests that emerge on burial grounds.

As Robinia profoundly changes habitat conditions due to its nitrogen-fixing capacity, this species might be hypothesized to induce an "invasional meltdown" [146] by facilitating other introduced species below its canopy. Correspondingly, Von Holle et al. [147] reported higher numbers of alien species in Robinia stands compared to native forest patches, which led the authors to address Robinia stands as "islands of invasion" in nutrient-poor native forest systems. Yet previous testing for the invasional meltdown hypothesis has led to ambiguous results and little support at the community level [148]. The absence of significant differences between numbers of alien species in alien Robinia vs. native Betula stands in our study does not support the invasional meltdown hypothesis. This contrasts 
with a study on the same invasive tree species in a rural North American setting [147] and highlights the need to consider the context dependence in assessing invasion impacts $[149,150]$. In our study, the high propagule pressure of alien species in Berlin obviously translates to a considerable but not dominating share of alien species of about $25 \%$ across all forest types. Indeed, propagule pressure has been found to better predict invasion success in urban tree stands than resource availability (and competitors) in the understory vegetation [151]. Native species generally prevailed in the understory forest assemblages with shares of about 75\% in Betula and Robinia forests and 65\% in Acer forests.

Interestingly, increased numbers of alien plant species in the plots were not related to a decrease in native richness. Numbers of native and alien plant species were instead significantly positively related-consistently across all forest types (Figure 7). This result matches the "the rich-get-richer" phenomenon, which has largely been reported at broader spatial scales [152-154]. Correspondingly, urban biodiversity studies have revealed urban ecosystems harboring a wealth of both native and alien species [23,155,156]. Dyderski et al. [78], for example, found a positive relationship between richness of alien and native tree species in remnants of riparian forests. Yet at finer spatial scales as in our study, negative associations between native and alien richness often, but not exclusively prevail, e.g., due to a higher importance of biotic interactions compared to niche heterogeneity at higher spatial scales [154]. Given the high variability of the alien-native patterns across scales, ecosystems, and regions, Fridley et al. [154] conclude that broad generalizations are poorly supported by scientific evidence. Our study highlights emerging urban forests in Berlin as shared habitats of alien and native species where drivers of species richness such as proximity to seed sources and availability of environmental resources shaped native and alien richness in a similar way.

The idea that the high representation of alien species in urban floras generally translates to a threat to native species thus finds no support for emerging urban forests in Berlin. Given the context dependence of invasion impacts [149], these results cannot be generalized for other regions. In North American cities, for example, highly competitive alien vine species can decrease species richness and tree regenerations considerably $[64,157]$. Such contrasting results from different regions highlight the need to consider context dependence of ecological effects in invasion assessments [150]. Gaertner et al. [158] argue for differentiating strategies for managing alien species in urban environments between species that have been classified as invasive or non-invasive. Robinia, as one of the dominant species of emerging urban forests in Berlin, has been generally classified as invasive due to negative impacts that had mostly been reported for grasslands and other (semi)open vegetation types [94,95]. Since our study does not provide evidence of deleterious effects of Robinia on the native diversity of emerging forests compared to other dominant tree species, we argued for assessing alien species based on their demonstrated effects in the specific environmental context. This requires context-dependent decisions for managing—or even conserving—Robinia forests as proposed by [159].

\subsubsection{Community Structure}

The species composition of ruderal succession stages usually diverges from succession series on non-urban sites [37]. Our study revealed the role of the dominant tree species in further modulating species assemblages and successional trends in urban emerging forests. The NMDS (Figure 6) showed that the community structures of plant and invertebrates were significantly related to forest type (Betula vs. Robinia vs. Acer) and forests origin (successional vs. rewilded). This was most obvious for plant species. For invertebrates, patches of rewilded Acer forests were clearly separated from the two types of successional forests. As a future direction, effects of forest origin (rewilded vs. successional) should be untangled from effects related to the identity of the dominant tree species, based on a larger data set. Results of this study indicate that community composition is determined by factors beyond species richness. Correspondingly, a North American study on regenerated forest patches differentiated communities as dominated by either native or alien tree species [13].

The differentiation of species assemblages is likely driven by habitat filtering due to the identity of the dominant tree species and associated differences in vegetation structure. Betula stands are generally 
light, whereas Robinia stands have a light canopy but a dense shrub layer; Acer stands usually present a closed canopy and a dense shrub layer. Moreover, as described above, $\mathrm{N}$-availability for plants is enhanced in Robinia stands due to $\mathrm{N}_{2}$-fixation, which facilitates the establishment of other species in the understory compared to other forest types [95,160].

Structural differences between forest stands usually translate to different biodiversity patterns of animal species (e.g., [161,162] for birds). In an Australian study, the volume of the understory vegetation was an important predictor for species richness in different groups of animals [163]. In our study, however, it was not species richness but community structure of invertebrates that differed among forest types. Correspondingly, Hejda et al. [144] found conspicuous differences in species composition but not species richness of three taxonomic groups in Robinia forests compared to native forests. Despite a considerable share of alien species, the emerging forests harbored different sets of associated plant and invertebrate species. This confirms corresponding results for plant communities of Robinia and Betula stands in the same study region about $25-50$ years ago $[137,164]$ and indicates that a conversion of community structure in the course of succession is missing thus far.

\subsubsection{Successional Trends}

A large number of both native and alien tree species were able to establish in the ground and shrub layers of the emerging urban forests, with differing patterns across forest types (Figure 5). Contrary to many expectations of recruitment limitations in native woody species in urban regions [165], there was no lack in the regeneration of native tree species from urban seed sources. The recruitment of native and alien trees can indicate the future development of the emerging forest types.

The dominant tree species of the canopy were also common in the shrub layer of the respective forest types, but for B. pendula and R. pseudoacacia this was less true in the ground layer. The latter is likely due to the high demands for light in these species [151] and might indicate a future change of dominance in the upper vegetation layers. The high frequency of trees typical of native oak-pine forests (Quercus robur and Sorbus aucuparia) indicates a development of Betula stands towards this type of native forest vegetation, which prevails on nutrient-poor sandy soils of the post-glacial landscape around Berlin [166]. Yet other species that are atypical of native oak-pine forests were frequently found in the Betula stands, including the native A. platanoides and the alien A. pseudoplatanus and, surprisingly, the native Fagus sylvatica. These species indicate enhanced nutrient availability, a common feature of urban environments [167]. Correspondingly, the enormous increase in abundance of Acer species in Berlin during the last 150 years has been explained as an urbanization effect, due to nitrogen influx from urban sources $[79,101]$. We thus concluded that emerging forests that are currently dominated by the native pioneer tree $B$. pendula would approach late successional native forest vegetation, yet with novel species combinations that include both native and alien Acer species and a mixture of native and alien plants in the ground layer as well.

The high frequency of Acer species in all vegetation layers of the Acer forests indicates that this novel forest type will persist for a longer time in rewilded greenspaces. Predictions for the Robinia forests are less clear. A fast decay of Robinia forests had been predicted in the 1960s, reflecting the pioneer character of this species in its native North American range [137]. Indeed, pioneer stands in the Appalachians are being replaced within a period of less than 30 years, mainly due to damaging stem borers and the presence of highly competitive late successional tree species [168]. In Berlin, however, 40-year-old stands were still vigorous around 1990, indicating that the life span of Robinia in Europe can be longer than in its native range, likely due to the absence of herbivore pressure [164]. Today, i.e., another 30 years later, several large Robinia stems have been noted dying off in emerging forests (pers. observation). Still, Robinia is able to grow root sprouts below its canopy [169]. The question remains, however, whether these sprouts can take over in the future to prolong the dominance of Robinia in emerging forests. A further confounding parameter is the potential shading out of the light-demanding Robinia by Acer species. Shade-tolerant Acer species are frequent in Robinia (and Betula) forests (Figure 5). However, whether these saplings will outcompete the less shade-tolerant 
Robinia in the future-and analogously the Quercus species in the Betula forests-is an open question as well. The growth of Acer species may be constrained by drought stress on many urban sites such as derelict railway areas. This might result in a co-dominance of Robinia and Acer species in more mature forest patches too.

Overall, these results suggest that community assembly in emerging forests of Berlin has resulted in different forest types with a distinct community structure and a large suite of juvenile tree species. The latter indicates different trajectories to more mature forests but with uncertainties about the direction and speed of future development. Acer forests in rewilded greenspaces will likely persist for a longer time, and changes in dominance patterns will likely occur faster in Betula stands than in Robinia stands.

The (co-)dominance of alien tree species in the canopy of Robinia and Acer forests resulted in distinct plant and invertebrate species assemblages. The native Betula forests also harbored a considerable share of alien species. Berlin's emerging urban forests thus represent novel urban ecosystems with regard to both dimensions of novel ecosystems [170]: novel environmental conditions (i.e., the anthropogenic sites) and novel assemblages of alien and native species. Beyond alien plant species, some native tree species also contribute to novel species assemblages. Most prominently, A. platanoides, a formerly rare species of the pristine forest vegetation, currently is and will remain abundant in all forest types, including the native Betula forests.

The co-existence of alien and native species in urban emerging forests seems to be a global phenomenon that extends beyond Berlin. Stewart et al. [88] suggested that native forest regeneration in cities of New Zealand may proceed by involving mixtures of alien and native woody species; this has also been demonstrated for successional forests on abandoned land in Puerto Rico [38,171]. These novel forest types will continue to differ from native forests in the future while still providing habitats for a number of native and alien species that are well adapted to urban conditions.

\subsubsection{Endangered Species}

Despite a sharp increase in urban biodiversity studies, Shwartz et al. [172] conclude in their meta-analysis that the contribution of cities to biodiversity conservation has not yet been sufficiently demonstrated. One reason is that biodiversity conservation can not necessarily be described simply in terms of species richness and numbers of native species, e.g., due to different relevance of common versus rare or endangered species. Recent studies have shown that cities can also host a considerable number of endangered species, e.g., [173]. This is true of novel urban ecosystems as well, as shown for Berlin [23,174] and beyond [42]. Our study contributes insights into the role of alien- vs. native-dominated emerging forests for endangered species of different taxonomic groups since Red Lists of endangered plants, spiders, and carabid beetles were available for the city of Berlin.

The emerging forest types harbored a limited set of species of conservation concern. While on average each forest patch harbored 1-2 endangered invertebrate species, an endangered plant species was only found in about 1 out of 10 patches. Accordingly, Planchuelo et al. [174] revealed a significantly lower probability of occurrence of highly endangered plant species in forests that had been classified as novel ecosystems. In contrast, natural forest remnants harbored the highest number of populations of highly endangered plant species. The scarcity of endangered plant species in the emerging forests of Berlin can likely be explained in two ways. First, rare habitat specialists of open ecosystems can be lost during early- and mid-successional transitions to tree-dominated vegetation [65,132]. Second, dispersal may be limited in many endangered plant species [175], especially in ancient forest species [176,177], preventing them from colonizing young emerging forests. Correspondingly, forest species of carabid beetles are largely confined to the urban fringe of European cities [115]. In the same vein, many invertebrate taxa of an urban forest remnant in New Zealand were not able to colonize other forest stands [24].

From a species protection perspective, the emerging forest patches support some habitat functions for endangered species of plants, spiders, and carabids. The number of species of conservation 
interest could increase over time as shown for other secondary forests [176]. Since we could not detect any effect of the introduction status of the dominant tree species on the occurrence of endangered species—consistently among plants and invertebrates (Figure 4)—our study indicates that it is not alien dominance in the canopy but rather other environmental parameters that limited the establishment of endangered species across all forest types.

\section{Conclusions on the Role of Emerging Forests for Urban Green Infrastructure}

Endangered species are important indicators of the conservation value of their habitats but do not represent the total range of targets of biodiversity conservation [178]. Particularly in an urban context, goals of biodiversity conservation should also include the role of urban nature for liveable environments for urban dwellers [179]. It is thus necessary to include a range of socially and ecologically based goals when discussing the role of emerging urban forests for developing the urban green infrastructure. Based on previous work [10,141,179-182], we here highlighted six ways in which emerging forests can contribute to developing biodiverse and liveable cities:

1. Preserve native biodiversity and populations of endangered species. All types of emerging urban forests harbored a considerable number of native plant and invertebrate species-despite a considerable share of alien species. Their role as habitat for endangered species was limited but may increase with time. Yet most likely, the emerging urban forests will not be able to approach natural forest remains in the near future. This strongly supports the well-established aim of placing the highest priority on protecting natural forest remnants in cities, e.g., [21], and indicates as well some opportunities for native species in novel urban settings.

2. Create ecological networks with stepping stones or corridors for plants and animals. While ecological network functions were not studied here, emerging urban forests likely support ecological networks by providing forest patches dispersed over the urban fabric that may be used as stepping stones for birds and other animals [42,140]. Since the alien Robinia forests harbored similar numbers of (endangered) invertebrates as the other forest types, they also contribute to ecological networks, e.g., for pollinators [183] or at higher trophic levels [95,144].

3. Facilitate and elucidate the adaptation of ecological systems to urbanization and other environmental pressures. Urbanization as a major driver of change in the Anthropocene period affects all components of urban ecosystems [184]. In consequence, novel urban ecosystems arise and support the understanding of how species assembly responds to a combination of novel environmental drivers in urban settings $[141,185]$. Allowing emerging forests to develop without intervening in the diversity patterns of alien and native species will provide insights into the adaptation of forest systems to changing urban environments, including interactions with climate change effects; and will allow conclusions to be drawn on the resilience of species and communities to urban pressures, and selection of suitable native or alien species for urban greenspaces.

4. Re-connect people with nature and support experience of natural elements. The diversity of both species assemblages and structural features of emerging urban forests and their adjacency to urban residents create manifold opportunities to experience natural elements and their dynamics in the neighborhood. This is an important service in times of decreasing experience in nature [186], with anticipated positive feedbacks to people's willingness to protect biodiversity [187], and a strong argument for conserving emerging forests close to places where people live [188].

5. Enhance wilderness in cities. Since wilderness areas significantly decline at a global scale [2], the aim of promoting wilderness areas in urban environments-complementing the highly managed ecosystems in public and private greenspaces-is on the urban agenda [70]. Emerging urban forests represent a kind of "novel urban wilderness," with species assemblages contrasting with the "ancient wilderness" of natural forest remnants but similarly shaped by natural processes [104]. While ancient wilderness areas are usually located at the urban fringe, emerging 
urban forests are often integrated into the urban fabric and thus can support access to wilderness in the daily life of urban residents.

6. Provide ecosystem services for urban people. There is increasing evidence of positive feedback between biodiversity and the provision of ecosystem services in cities [189]. Emerging forests in particular, including abundant alien tree species, have been shown to provide a range of regulating ecosystem services on vacant land [44,46]. Moreover, they constitute informal greenspaces [190] supporting manifold social uses and cultural services [191-193]. Importantly, these ecosystem services are being delivered without the use of resources to produce plants and carry out landscaping and maintenance; thus they have a low $\mathrm{CO}_{2}$ footprint. Integrating emerging forests into the urban green infrastructure therefore also contributes to both climate change mitigation and adaptation.

Although there are many reasons for integrating emerging urban forests into the green infrastructure of cities, some important challenges remain. Studies on the extent to which people value wild vegetation on urban vacant lots have yielded ambiguous results. While some studies revealed prevailing positive valuations of wild vegetation in urban settings [9,71], other studies showed that people preferred open succession stages over woody stages [194,195]. This is likely related to concerns about safety and to general cross-cultural preferences for semi-open scenery [196]. Moreover, rubbish and other signs of neglect may reduce the acceptance of emerging urban forests, necessitating "orderly frames" to improve public perception [191,197]. As with spontaneous vegetation in general [198-200], integrating emerging urban forests into urban green systems thus often requires planning, design interventions, and management to mitigate risks and enhance the opportunities that this novel type of urban woodland offers for the development of biodiverse and liveable green cities. The successful integration of emerging forests in newly established formal parks and greenways in Berlin [103-105], the post-industrial landscape of the Ruhr region [50] and beyond, e.g., [201], illustrates promising perspectives for enhancing the wild side of urban green infrastructure.

Author Contributions: Conceptualization, I.K.; data curation, A.H., G.P. and B.S.; formal analysis, S.B. and G.P.; investigation, A.H., B.S. and S.B.; methodology, I.K., B.S., M.v.d.L. and S.B.; project administration, B.S.; supervision, I.K., M.v.d.L. and S.B.; visualization, I.K., A.H. and G.P.; writing-original draft, I.K.; writing-review and editing, A.H., G.P., B.S., M.v.d.L. and S.B.

Funding: Parts of this research were financed by Deutsche Bundesstiftung Umwelt (DBU project AZ 29773, "Integration von Naturschutzzielen bei der Bewahrung und Entwicklung des Jüdischen Friedhofs Berlin-Weißensee" and by the German Federal Ministry of Education and Research BMBF within the Collaborative Project "Bridging in Biodiversity Science-BIBS" (funding number 01LC1501).

Acknowledgments: We thank Theo Blick and Karsten Hannig for spider and carabid determination, Giovanni Trentanovi and Dennis Born for sampling some plant data and Andreas Lemke for assistance during field work. Many thanks to Lea Johnson for stimulating this paper and to Kelaine Ravdin and anonymous reviewers for comments on a previous version.

Conflicts of Interest: The authors declare no conflict of interest.

\section{References}

1. Hedblom, M.; Soderstrom, B. Woodlands across Swedish urban gradients: Status, structure and management implications. Landsc. Urban Plan. 2008, 84, 62-73. [CrossRef]

2. Ellis, E.C. Ecology in an anthropogenic biosphere. Ecol. Monogr. 2015, 85, 287-331. [CrossRef]

3. Wu, Y.Y.; Li, S.Y.; Yu, S.X. Monitoring urban expansion and its effects on land use and land cover changes in Guangzhou city, China. Environ. Monit. Assess. 2016, 188, 54. [CrossRef] [PubMed]

4. Croci, S.; Butet, A.; Georges, A.; Aguejdad, R.; Clergeau, P. Small urban woodlands as biodiversity conservation hot-spot: A multi-taxon approach. Landsc. Ecol. 2008, 23, 1171-1186. [CrossRef]

5. Grigorescu, I.; Geacu, S. The dynamics and conservation of forest ecosystems in Bucharest Metropolitan Area. Urban For. Urban Green. 2017, 27, 90-99. [CrossRef]

6. Konijnendijk, C.C. The Forest and the City. The Cultural Landscape of Urban Woodland, 2nd ed.; Springer: Dordrecht, The Netherlands, 2018. 
7. Nesbitt, L.; Hotte, N.; Barron, S.; Cowan, J.; Sheppard, S.R.J. The social and economic value of cultural ecosystem services provided by urban forests in North America: A review and suggestions for future research. Urban For. Urban Green. 2017, 25, 103-111. [CrossRef]

8. Endreny, T.A. Strategically growing the urban forest will improve our world. Nat. Commun. 2018, 9, 1160. [CrossRef] [PubMed]

9. Fischer, L.K.; Honold, J.; Cvejic, R.; Delshammar, T.; Hilbert, S.; Lafortezza, R.; Nastran, M.; Nielsen, A.B.; Pintar, M.; van der Jagt, A.P.N.; et al. Beyond green: Broad support for biodiversity in multicultural European cities. Glob. Environ. Chang. 2018, 49, 35-45. [CrossRef]

10. Jim, C.Y. Conservation and Creation of Urban Woodlands. In Greening Cities; Tan, P., Jim, C., Eds.; Advances in 21st Century Human Settlements; Springer: Singapore, 2017; pp. 307-330.

11. Yao, N.; Konijnendijk van den Bosch, C.C.; Yang, J.; Devisscher, T.; Wirtz, Z.; Jia, L.; Duan, J.; Ma, L. Beijing's 50 million new urban trees: Strategic governance for large-scale urban afforestation. Urban For. Urban Green. 2019, 44, 126392. [CrossRef]

12. Toni, S.A.; Duinker, P.N. A framework for urban-woodland naturalization in Canada. Environ. Rev. 2015, 23, 321-336. [CrossRef]

13. Zipperer, W.C. Species composition and structure of regenerated and remnant forest patches within an urban landscape. Urban Ecosyst. 2002, 6, 271-290. [CrossRef]

14. Kowarik, I. Wild Urban Woodlands: Towards a Conceptual Framework. In Wild Urban Woodlands. New Perspectives for Urban Forestry; Kowarik, I., Körner, S., Eds.; Springer: Berlin/Heidelberg, Germany, 2005; pp. 1-32.

15. Pougy, N.; Martins, E.; Verdi, M.; de Oliveira, J.A.; Maurenza, D.; Amaro, R.; Martinelli, G. Urban forests and the conservation of threatened plant species: The case of the Tijuca National Park, Brazil. Nat. Conserv. 2014, 12, 170-173. [CrossRef]

16. Clews, E.; Corlett, R.T.; Ho, J.K.I.; Kim, D.E.; Koh, C.Y.; Liong, S.-Y.; Meier, R.; Memory, A.; Ramchunder, S.; Sin, T.M.; et al. The biological, ecological and conservation significance of freshwater swamp forest in Singapore. Gard. Bull. Singap. 2018, 70, 9-31. [CrossRef]

17. Rudnicky, J.L.; McDonnell, M.J. 48 Years of Canopy Change in a Hardwood-Hemlock Forest in New-York-City. Bull. Torrey Bot. Club 1989, 116, 52-64. [CrossRef]

18. Godefroid, S.; Koedam, N. How important are large vs. small forest remnants for the conservation of the woodland flora in an urban context? Glob. Ecol. Biogeogr. 2003, 12, 287-298. [CrossRef]

19. Mandryk, A.M.; Wein, R.W. Exotic vascular plant invasiveness and forest invasibility in urban boreal forest types. Biol. Invasions 2006, 8, 1651-1662. [CrossRef]

20. Korzhinevskaya, A.A.; Veselkin, D.V. The Richness and Cover of Alien Plants in the Undergrowth and Field Layer of Urbanized Southern Taiga Forests. KnE Life Sci. 2018, 95-103.

21. Godefroid, S.; Koedam, N. Distribution pattern of the flora in a peri-urban forest: An effect of the city-forest ecotone. Landsc. Urban Plan. 2003, 65, 169-185. [CrossRef]

22. Dyderski, M.K.; Tyborski, J.; Jagodzinski, A.M. The utility of ancient forest indicator species in urban environments: A case study from Poznan, Poland. Urban For. Urban Green. 2017, 27, 76-83. [CrossRef]

23. Kowarik, I.; von der Lippe, M. Plant population success across urban ecosystems: A framework to inform biodiversity conservation in cities. J. Appl. Ecol. 2018, 55, 2354-2361. [CrossRef]

24. Toft, R.J.; Ford, D.E.; Sullivan, J.J.; Stewart, G.H. Invertebrates of an urban old growth forest are different from forest restoration and garden communities. N. Z. J. Ecol. 2019, 43, 3350. [CrossRef]

25. Salvati, L.; Ranalli, F.; Carlucci, M.; Ippolito, A.; Ferrara, A.; Corona, P. Forest and the city: A multivariate analysis of peri-urban forest land cover patterns in 283 European metropolitan areas. Ecol. Indic. 2017, 73, 369-377. [CrossRef]

26. Oldfield, E.E.; Warren, R.J.; Felson, A.J.; Bradford, M.A. Challenges and future directions in urban afforestation. J. Appl. Ecol. 2013, 50, 1169-1177. [CrossRef]

27. Johnson, L.R.; Handel, S.N. Restoration treatments in urban park forests drive long-term changes in vegetation trajectories. Ecol. Appl. 2016, 26, 940-956. [CrossRef] [PubMed]

28. McPhearson, P.T.; Feller, M.; Felson, A.; Karty, R.; Lu, J.W.T.; Palmer, M.I.; Wenskus, T. Assessing the Effects of the Urban Forest Restoration Effort of MillionTreesNYC on the Structure and Functioning of New York City Ecosystems. Cities Environ. 2010, 3, 1-21. [CrossRef] 
29. Wallace, K.J.; Clarkson, B.D. Urban forest restoration ecology: A review from Hamilton, New Zealand. J. R. Soc. N. Z. 2019, 49, 347-369. [CrossRef]

30. Hotta, K.; Ishii, H.; Sasaki, T.; Doi, N.; Azuma, W.; Oyake, Y.; Imanishi, J.; Yoshida, H. Twenty-one years of stand dynamics in a 33-year-old urban forest restoration site at Kobe Municipal Sports Park, Japan. Urban For. Urban Green. 2015, 14, 309-314. [CrossRef]

31. Simmons, B.L.; Hallett, R.A.; Sonti, N.F.; Auyeung, D.S.N.; Lu, J.W.T. Long-term outcomes of forest restoration in an urban park. Restor. Ecol. 2016, 24, 109-118. [CrossRef]

32. Guo, X.Y.; Li, W.L.; Da, L.J. Near-Natural Silviculture: Sustainable Approach for Urban Renaturalization? Assessment Based on 10 Years Recovering Dynamics and Eco-Benefits in Shanghai. J. Urban. Plan. Dev. 2015, 141, A5015001. [CrossRef]

33. Anderson, E.C.; Minor, E.S. Vacant lots: An underexplored resource for ecological and social benefits in cities. Urban For. Urban Green. 2017, 21, 146-152. [CrossRef]

34. Rink, D.; Arndt, T. Investigating perception of green structure configuration for afforestation in urban brownfield development by visual methods. A case study in Leipzig, Germany. Urban For. Urban Green. 2016, 15, 65-74. [CrossRef]

35. Sasaki, T.; Ishii, H.; Morimoto, Y. Evaluating restoration success of a 40-year-old urban forest in reference to mature natural forest. Urban For. Urban Green. 2018, 32, 123-132. [CrossRef]

36. Peterken, G.F. Woodland Conservation and Management; Chapman and Hall: London, UK; New York, NY, USA, 1981; 328p.

37. Prach, K.; Pyšek, P.; Bastl, M. Spontaneous vegetation succession in human-disturbed habitats: A pattern across seres. Appl. Veg. Sci. 2001, 4, 83-88. [CrossRef]

38. Lugo, A.E.; Helmer, E. Emerging forests on abandoned land: Puerto Rico's new forests. For. Ecol. Manag. 2004, 190, 145-161. [CrossRef]

39. Thorn, S.; Bassler, C.; Brandl, R.; Burton, P.J.; Cahall, R.; Campbell, J.L.; Castro, J.; Choi, C.Y.; Cobb, T.; Donato, D.C.; et al. Impacts of salvage logging on biodiversity: A meta-analysis. J. Appl. Ecol. 2018, 55, 279-289. [CrossRef] [PubMed]

40. Kowarik, I. Vegetationsentwicklung auf innerstädtischen Brachflächen. Beispiele aus Berlin (West). Tuexenia 1986, 6, 75-98.

41. Kunick, W. Spontaneous Woody Vegetation in Cities. In Urban Ecology: Plants and Plant Communities in Urban Environments; Sukopp, H., Hejny, S., Kowarik, I., Eds.; SPB Academic Publishing: The Hague, The Netherlands, 1990; pp. 167-174.

42. Bonthoux, S.; Brun, M.; Di Pietro, F.; Greulich, S.; Bouche-Pillon, S. How can wastelands promote biodiversity in cities? A review. Landsc. Urban Plan. 2014, 132, 79-88. [CrossRef]

43. Prach, K.; Řehounková, K.; Lencová, K.; Jírová, A.; Konvalinková, P.; Mudrák, O.; Študent, V.; Vaněček, Z.; Tichý, L.; Petř́k, P.; et al. Vegetation succession in restoration of disturbed sites in Central Europe: The direction of succession and species richness across 19 seres. Appl. Veg. Sci. 2014, 17, 193-200. [CrossRef]

44. Kim, G.; Miller, P.A.; Nowak, D.J. Assessing urban vacant land ecosystem services: Urban vacant land as green infrastructure in the City of Roanoke, Virginia. Urban For. Urban Green. 2015, 14, 519-526. [CrossRef]

45. Sitzia, T.; Campagnaro, T.; Weir, R.G. Novel woodland patches in a small historical Mediterranean city: Padova, Northern Italy. Urban Ecosyst. 2016, 19, 475-487. [CrossRef]

46. Riley, C.B.; Herms, D.A.; Gardiner, M.M. Exotic trees contribute to urban forest diversity and ecosystem services in inner-city Cleveland, OH. Urban For. Urban Green. 2018, 29, 367-376. [CrossRef]

47. Johnson, A.L.; Borowy, D.; Swan, C.M. Land use history and seed dispersal drive divergent plant community assembly patterns in urban vacant lots. J. Appl. Ecol. 2018, 55, 451-460. [CrossRef]

48. Westermann, J.R.; von der Lippe, M.; Kowarik, I. Seed traits, landscape and environmental parameters as predictors of species occurrence in fragmented urban railway habitats. Basic Appl. Ecol. 2011, 12, $29-37$. [CrossRef]

49. Trentanovi, G.; von der Lippe, M.; Sitzia, T.; Ziechmann, U.; Kowarik, I.; Cierjacks, A. Biotic homogenization at the community scale: Disentangling the roles of urbanization and plant invasion. Divers. Distrib. 2013, 19, 738-748. [CrossRef]

50. Dettmar, J. Forest for shrinking cities. In Wild Urban Woodlands. New Perspectives for Urban Forestry; Kowarik, I., Körner, S., Eds.; Springer: Berlin/Heidelberg, Germany, 2005; pp. 263-277. 
51. Kowarik, I.; Körner, S. Wild Urban Woodlands. New Perspectives for Urban Forestry; Springer: Berlin/Heidelberg, Germany, 2005; 299p.

52. Weiss, J.; Burghardt, W.; Gausmann, P.; Haag, R.; Haupler, H.; Hamann, M.; Leder, B.; Schulte, A.; Stempelmann, I. Nature Returns to Abandoned Industrial Land: Monitoring Succession in Urban-Industrial Woodlands in the German Ruhr. In Wild Urban Woodlands. New Perspectives for Urban Forestry; Kowarik, I., Körner, S., Eds.; Springer: Berlin/Heidelberg, Germany, 2005; pp. 143-162.

53. Rebele, F.; Lehmann, C. Restoration of a landfill site in Berlin, Germany by spontaneous and directed succession. Restor. Ecol. 2002, 10, 340-347. [CrossRef]

54. Rebele, F.; Lehmann, C. Twenty years of woodland establishment through natural succession on a sandy landfill site in Berlin, Germany. Urban For. Urban Green. 2016, 18, 182-189. [CrossRef]

55. Corlett, R.T. Restoration, Reintroduction, and Rewilding in a Changing World. Trends Ecol. Evol. 2016, 31, 453-462. [CrossRef] [PubMed]

56. Zerbe, S. Restoration of natural broad-leaved woodland in Central Europe on sites with coniferous forest plantations. For. Ecol. Manag. 2002, 167, 27-42. [CrossRef]

57. Gonzalez, E.; Masip, A.; Tabacchi, E. Poplar plantations along regulated rivers may resemble riparian forests after abandonment: A comparison of passive restoration approaches. Restor. Ecol. 2016, 24, 538-547. [CrossRef]

58. Vojta, J. Relative importance of historical and natural factors influencing vegetation of secondary forests in abandoned villages. Preslia 2007, 79, 223-244.

59. Pandi, I.; Penksza, K.; Botta-Dukat, Z.; Kroel-Dulay, G. People move but cultivated plants stay: Abandoned farmsteads support the persistence and spread of alien plants. Biodivers. Conserv. 2014, 23, 1289-1302. [CrossRef]

60. Gilbert, O.L. The Ecology of Urban Habitats; Chapman and Hall: London, UK; New York, NY, USA, 1989; 369p.

61. Cloke, P.; Jones, O. Turning in the graveyard: Trees and the hybrid geographies of dwelling, monitoring and resistance in a Bristol cemetery. Cult. Geogr. 2004, 11, 313-341. [CrossRef]

62. Kowarik, I.; Buchholz, S.; von der Lippe, M.; Seitz, B. Biodiversity functions of urban cemeteries: Evidence from one of the largest Jewish cemeteries in Europe. Urban For. Urban Green. 2016, 19, 68-78. [CrossRef]

63. Gandy, M. The fly that tried to save the world: Saproxylic geographies and other-than-human ecologies. T I Brit. Geogr. 2019, 44, 392-406. [CrossRef] [PubMed]

64. Pregitzer, C.C.; Charlop-Powers, S.; Bibbo, S.; Forgione, H.M.; Gunther, B.; Hallett, R.A.; Bradford, M.A. A city-scale assessment reveals that native forest types and overstory species dominate New York City forests. Ecol. Appl. 2019, 29, e01819. [CrossRef] [PubMed]

65. Schadek, U.; Strauss, B.; Biedermann, R.; Kleyer, M. Plant species richness, vegetation structure and soil resources of urban brownfield sites linked to successional age. Urban Ecosyst. 2009, 12, 115-126. [CrossRef]

66. Prach, K. Spontaneous succession in Central-European man-made habitats: What information can be used in restoration practice? Appl. Veg. Sci. 2003, 6, 125-129. [CrossRef]

67. Walker, L.R.; Walker, J.; Hobbs, R.J. Linking Restoration and Ecological Succession; Springer: London, UK, 2007; 188p.

68. Prach, K.; Hobbs, R.J. Spontaneous succession versus technical reclamation in the restoration of disturbed sites. Restor. Ecol. 2008, 16, 363-366. [CrossRef]

69. Pettorelli, N.; Durant, S.M.; du Troit, J.T. Rewilding; Cambridge University Press: Cambridge, UK, 2019; 437p.

70. McKinney, M.; Kowarik, I.; Kendal, D. Wild urban ecosystems: Challenges and opportunities for urban development. Urban For. Urban Green. 2018, 29, 334-403. [CrossRef]

71. Hwang, Y.H.; Yue, Z.E.J.; Ling, S.K.; Tan, H.H.V. It's ok to be wilder: Preference for natural growth in urban green spaces in a tropical city. Urban For. Urban Green. 2019, 38, 165-176. [CrossRef]

72. Borgmann, K.L.; Rodewald, A.D. Forest restoration in urbanizing landscapes: Interactions between land uses and exotic shrubs. Restor. Ecol. 2005, 13, 334-340. [CrossRef]

73. Sullivan, J.J.; Meurk, C.; Whaley, K.J.; Simcock, R. Restoring native ecosystems in urban Auckland: Urban soils, isolation, and weeds as impediments to forest establishment. N. Z. J. Ecol. 2009, 33, 60-71.

74. Ishii, H.; Ichinose, G.; Ohsugi, Y.; Iwasaki, A. Vegetation recovery after removal of invasive Trachycarpus fortunei in a fragmented urban shrine forest. Urban For. Urban Green. 2016, 15, 53-57. [CrossRef] 
75. Gaertner, M.; Wilson, J.R.U.; Cadotte, M.W.; MacIvor, J.S.; Zenni, R.D.; Richardson, D.M. Non-native species in urban environments: Patterns, processes, impacts and challenges. Biol. Invasions 2017, 19, 3461-3469. [CrossRef]

76. Chocholoušková, Z.; Pyšek, P. Changes in composition and structure of urban flora over 120 years: A case study of the city of Plzeň. Flora 2003, 198, 366-376. [CrossRef]

77. Knapp, S.; Kühn, I.; Stolle, J.; Klotz, S. Changes in the functional composition of a Central European urban flora over three centuries. Perspect. Plant. Ecol. 2010, 12, 235-244. [CrossRef]

78. Dyderski, M.K.; Gdula, A.K.; Jagodzinski, A.M. “The rich get richer” concept in riparian woody species-A case study of the Warta River Valley (Poznan, Poland). Urban For. Urban Green. 2015, 14, 107-114. [CrossRef]

79. Kowarik, I.; von der Lippe, M.; Cierjacks, A. Prevalence of alien versus native species of woody plants in Berlin differs between habitats and at different scales. Preslia 2013, 85, 113-132.

80. Duguay, S.; Eigenbrod, F.; Fahrig, L. Effects of surrounding urbanization on non-native flora in small forest patches. Landsc. Ecol. 2007, 22, 589-599. [CrossRef]

81. LaPaix, R.; Harper, K.; Freedman, B. Patterns of exotic plants in relation to anthropogenic edges within urban forest remnants. Appl. Veg. Sci. 2012, 15, 525-535. [CrossRef]

82. Sukopp, H.; Blume, H.P.; Elvers, H.; Horbert, M. Beiträge zur Stadtökologie von Berlin (West). Landsch. Umweltforsch. 1980, 3, 1-225.

83. Kim, G. Assessing Urban Forest Structure, Ecosystem Services, and Economic Benefits on Vacant Land. Sustainability 2016, 8, 679. [CrossRef]

84. MacDougall, A.S.; Turkington, R. Are invasive species the drivers or passengers of change in degraded ecosystems? Ecology 2005, 86, 42-55. [CrossRef]

85. Dyderski, M.K.; Jagodzinski, A.M. Context-Dependence of Urban Forest Vegetation Invasion Level and Alien Species' Ecological Success. Forests 2019, 10, 26. [CrossRef]

86. Stewart, G.H.; Meurk, C.D.; Ignatieva, M.E.; Buckley, H.L.; Magueur, A.; Case, B.S.; Hudson, M.; Parker, M. Urban Biotopes of Aotearoa New Zealand (URBANZ) II: Floristics, biodiversity and conservation values of urban residential and public woodlands, Christchurch. Urban For. Urban Green. 2009, 8, 149-162. [CrossRef]

87. Buchholz, S.; Tietze, H.; Kowarik, I.; Schirmel, J. Effects of a Major Tree Invader on Urban Woodland Arthropods. PLoS ONE 2015, 10, e0137723. [CrossRef] [PubMed]

88. Stewart, G.H.; Ignatieva, M.E.; Meurk, C.D.; Earl, R.D. The re-emergence of indigenous forest in an urban environment, Christchurch, New Zealand. Urban For. Urban Green. 2004, 2, 149-158. [CrossRef]

89. Pergl, J.; Sádlo, J.; Petř́k, P.; Danihelka, J.; Chrtek, J.; Hejda, M.; Moravcová, L.; Perglová, I.; Štajerová, K.; Pyšek, P. Dark side of the fence: Ornamental plants as a source of wild-growing flora in the Czech Republic. Preslia 2016, 88, 163-184.

90. Mayer, K.; Haeuser, E.; Dawson, W.; Essl, F.; Kreft, H.; Pergl, J.; Pyšek, P.; Weigelt, P.; Winter, M.; Lenzner, B.; et al. Naturalization of ornamental plant species in public green spaces and private gardens. Biol. Invasions 2017, 19, 3613-3627. [CrossRef]

91. Nordh, H.; Swensen, G. Introduction to the special feature "The role of cemeteries as green urban spaces". Urban For. Urban Green. 2018, 33, 56-57. [CrossRef]

92. Prach, K. Succession of Woody Species in Derelict Sites in Central-Europe. Ecol. Eng. 1994, 3, 49-56. [CrossRef]

93. Seitz, B.; Ristow, M.; Prasse, R.; Machatzki, B.; Klemm, G.; Böcker, R.; Sukopp, H. Der Berliner Florenatlas; Verhandlungen des Botanischen Vereins von Berlin und Brandenburg: Berlin, Germany, 2012; 533p.

94. Cierjacks, A.; Kowarik, I.; Joshi, J.; Hempel, S.; Ristow, M.; von der Lippe, M.; Weber, E. Biological Flora of the British Isles: Robinia pseudoacacia. J. Ecol. 2013, 101, 1623-1640. [CrossRef]

95. Vitková, M.; Muellerová, J.; Sádlo, J.; Pergl, J.; Pyšek, P. Black locust (Robinia pseudoacacia) beloved and despised: A story of an invasive tree in Central Europe. For. Ecol. Manag. 2017, 384, 287-302. [CrossRef] [PubMed]

96. Hilmers, T.; Friess, N.; Bassler, C.; Heurich, M.; Brandl, R.; Pretzsch, H.; Seidl, R.; Müller, J. Biodiversity along temperate forest succession. J. Appl. Ecol. 2018, 55, 2756-2766. [CrossRef]

97. Schirmel, J.; Bundschuh, M.; Entling, M.H.; Kowarik, I.; Buchholz, S. Impacts of invasive plants on resident animals across ecosystems, taxa, and feeding types: A global assessment. Glob. Chang. Biol. 2016, 22, 594-603. [CrossRef] [PubMed] 
98. Seibold, S.; Cadotte, M.W.; MacIvor, J.S.; Thorn, S.; Müller, J. The Necessity of Multitrophic Approaches in Community Ecology. Trends Ecol. Evol. 2018, 33, 754-764. [CrossRef] [PubMed]

99. Senatsverwaltung für Stadtentwicklung und Wohnen. Umweltatlas Berlin. 05.08 Biotoptypen (Ausgabe 2014). Available online: https://www.stadtentwicklung.berlin.de/umwelt/umweltatlas/k508.htm (accessed on 13 August 2019).

100. Kreyer, D.; Zerbe, S. Short-lived tree species and their role as indicators for plant diversity in the restoration of natural forests. Restor. Ecol. 2006, 14, 137-147. [CrossRef]

101. Sachse, U.; Starfinger, U.; Kowarik, I. Synanthropic woody species in the urban area of Berlin. In Urban Ecology: Plants and Plant Communities in Urban Environments; Sukopp, H., Hejny, S., Kowarik, I., Eds.; SPB Academic Publishing: The Hague, The Netherlands, 1990; pp. 233-243.

102. Arbeitsgruppe Artenschutzprogramm Berlin, Grundlagen für das Artenschutzprogramm Berlin. Landsch. Umweltforsch. 1984, 23, 1-999.

103. Lachmund, J. Greening Berlin: The Co-Production of Science, Politics, and Urban Nature; The MIT Press: Cambridge, MA, USA; London, UK, 2013; 320p.

104. Kowarik, I. Urban wilderness: Supply, demand, and access. Urban For. Urban Green. 2018, $29,336-347$. [CrossRef]

105. Kowarik, I. The "Green Belt Berlin": Establishing a greenway where the Berlin Wall once stood by integrating ecological, social and cultural approaches. Landsc. Urban Plan. 2019, 184, 12-22. [CrossRef]

106. Bornkamm, R. Spontaneous development of urban woody vegetation on differing soils. Flora 2007, 202, 695-704. [CrossRef]

107. Rebele, F. Differential succession towards woodland along a nutrient gradient. Appl. Veg. Sci. 2013, 16, 365-378. [CrossRef]

108. Platen, R.; Kowarik, I. Dynamik von Pflanzen-, Spinnen- und Laufkäfergemeinschaften bei der Sukzession von Trockenrasen zu Gehölzgesellschaften auf innerstädtischen Brachflächen in Berlin. Verh. d. Ges. f. Ökol. 1995, 24, 431-439.

109. Buchholz, S.; Blick, T.; Hannig, K.; Kowarik, I.; Lemke, A.; Otte, V.; Scharon, J.; Schonhofer, A.; Teige, T.; von der Lippe, M.; et al. Biological richness of a large urban cemetery in Berlin. Results of a multi-taxon approach. Biodivers. Data J. 2016, 4, e7057. [CrossRef] [PubMed]

110. Graf, A. Flora und Vegetation der Friedhöfe in Berlin (West). Verh. Berl. Bot. Ver. 1986, 5, 1-211.

111. Sachse, U. Die anthropogene Ausbreitung von Berg- und Spitzahorn: (Acer pseudoplatanus L. und Acer platanoides L.): Ökologische Voraussetzungen am Beispiel Berlins. Landsch. Umweltforsch. 1989, 63, 1-132.

112. Passarge, H. Ortsnahe Ahorn-Gehölze und Ahorn-Parkwaldgesellschaften. Tuexenia 1990, 10, 369-384.

113. QGIS Development Team. QGIS Geographic Information System; Open Source Geospatial Foundation Project; QGIS Development Team: Zürich, Switzerland, 2018.

114. McKinney, M. Effects of urbanization on species richness: A review of plants and animals. Urban Ecosyst. 2008, 11, 161-176. [CrossRef]

115. Niemela, J.; Kotze, D.J. Carabid beetle assemblages along urban to rural gradients: A review. Landsc. Urban Plan. 2009, 92, 65-71. [CrossRef]

116. Burkman, C.E.; Gardiner, M.M. Spider assemblages within greenspaces of a deindustrialized urban landscape. Urban Ecosyst. 2015, 18, 793-818. [CrossRef]

117. Buchholz, S.; Hannig, K.; Moller, M.; Schirmel, J. Reducing management intensity and isolation as promising tools to enhance ground-dwelling arthropod diversity in urban grasslands. Urban Ecosyst. 2018, 21, 1139-1149. [CrossRef]

118. Vergnes, A.; Pellissier, V.; Lemperiere, G.; Rollard, C.; Clergeau, P. Urban densification causes the decline of ground-dwelling arthropods. Biodivers. Conserv. 2014, 23, 1859-1877. [CrossRef]

119. Hennekens, S.M.; Schaminee, J.H.J. TURBOVEG, a comprehensive data base management system for vegetation data. J. Veg. Sci. 2001, 12, 589-591. [CrossRef]

120. Müller-Motzfeld, G.; Freude, H.; Harde, K.W.; Lohse, G.A.; Klausnitzer, B. Die Käfer Mitteleuropas. Band 2 Adephaga 1: Carabidae (Laufkäfer); Spektrum Akademischer Verlag: München, Germany, 2004; 521p.

121. Nentwig, W.; Blick, T.; Gloor, D.; Hänggi, A.; Kropf, C. Araneae. Spiders of Europe. Version 05.2015. Available online: https://www.araneae.nmbe.ch (accessed on 5 May 2015).

122. Roberts, M.J. The Spiders of Great Britain and Ireland; Harley Books: Colchester, UK, 1987.

123. Roberts, M.J. Spinnengids; Tirion: Baarn, The Netherlands, 1998; 397p. 
124. Kielhorn, K.H. Rote Liste und Gesamtartenliste der Laufkäfer (Coleoptera: Carabidae) von Berlin. In Rote Listen der gefährdeten Pflanzen und Tiere von Berlin; CD-ROM; Der Landesbeauftragte für Naturschutz und Landschaftspflege \& Senatsverwaltung für Stadtentwicklung: Berlin, Germany, 2005.

125. Kielhorn, U. Rote Liste und Gesamtartenliste der Spinnen (Araneae) und Gesamtartenliste der Weberknechte (Opiliones) von Berlin. In Rote Listen der gefährdeten Pflanzen, Pilze und Tiere von Berlin; Der Landesbeauftragte für Naturschutz und Landschaftspflege \& Senatsverwaltung für Umwelt, Verkehr und Klimaschutz: Berlin, Germany, 2017.

126. Seitz, B.; Ristow, M.; Meißner, J.; Machatzki, B.; Sukopp, H. Rote Liste und Gesamtartenliste der etablierten Farn- und Blütenpflanzen von Berlin. In Rote Listen der gefährdeten Pflanzen, Pilze und Tiere von Berlin; Der Landesbeauftrage für Naturschutz und Landschaftspflege \& Senatsverwaltung für Umwelt, Verkehr und Klimaschutz: Berlin, Germany, 2018.

127. Londo, G. The decimal scale for releves of permanent quadrats. Vegetatio 1976, 33, 61-64. [CrossRef]

128. Braun-Blanquet, J. Pflanzensoziologie, Grundzüge der Vegetationskunde; Springer: Wien, Austria, 1964; 865p.

129. R Core Team. R: A Language and Environment for Statistical Computing, version R-3.4.4; R Foundation for Statistical Computing: Vienna, Austria, 2016.

130. Hollander, M.; Wolfe, D.A. Nonparametric Statistical Methods; John Wiley \& Sons: New York, NY, USA, 1973.

131. Oksanen, J.; Blanchet, F.G.; Friendly, M.; Kindt, R.; Legendre, P.; McGlinn, D.; Minchin, P.R.; O’Hara, R.B.; Simpson, G.L.; Solymos, P.; et al. Vegan: Community Ecology Package. R Package Version 2.4-3. 2017. Available online: https://cran.r-project.org/src/contrib/Archive/vegan/ (accessed on 13 August 2019).

132. Kattwinkel, M.; Biedermann, R.; Kleyer, M. Temporary conservation for urban biodiversity. Biol. Conserv. 2011, 144, 2335-2343. [CrossRef]

133. Gardiner, M.M.; Burkman, C.E.; Prajzner, S.P. The Value of Urban Vacant Land to Support Arthropod Biodiversity and Ecosystem Services. Environ. Entomol. 2013, 42, 1123-1136. [CrossRef] [PubMed]

134. Křivánek, M.; Pyšek, P.; Jarošík, V. Planting history and propagule pressure as predictors of invasion by woody species in a temperate region. Conserv. Biol. 2006, 20, 1487-1498. [CrossRef] [PubMed]

135. Čeplová, N.; Lososová, Z.; Kalusová, V. Urban ornamental trees: A source of current invaders; a case study from a European City. Urban Ecosyst. 2017, 20, 1135-1140. [CrossRef]

136. Kowarik, I. Zur Verbreitung, Vergesellschaftung und Einbürgerung des Götterbaumes (Ailanthus altissima [MiII.] Swingle) in Mitteleuropa. Tuexenia 1984, 4, 9-29.

137. Kohler, A.; Sukopp, H. Über die Gehölzentwicklung auf Berliner Trümmerstandorten. Zugleich ein Beitrag zum Studium neophytischer Holzarten. Ber. Der Dtsch. Bot. Ges. 1964, 76, 389-407.

138. Dyderski, M.K.; Jagodzinski, A.M. Functional traits of acquisitive invasive woody species differ from conservative invasive and native species. Neobiota 2019, 41, 91-113. [CrossRef]

139. Honnay, O.; Endels, P.; Vereecken, H.; Hermy, M. The role of patch area and habitat diversity in explaining native plant species richness in disturbed suburban forest patches in northern Belgium. Divers. Distrib. 1999, 5, 129-141. [CrossRef]

140. Rastandeh, A.; Brown, D.K.; Pedersen Zari, M. Biodiversity conservation in urban environments: A review on the importance of spatial patterning of landscapes. In Proceedings of the Ecocity World Summit, Melbourne, Australia, 12-14 July 2017; pp. 12-14.

141. Kowarik, I. Novel urban ecosystems, biodiversity, and conservation. Environ. Pollut. 2011, 159, $1974-1983$. [CrossRef] [PubMed]

142. Schirmel, J.; Timler, L.; Buchholz, S. Impact of the invasive moss Campylopus introflexus on carabid beetles (Coleoptera: Carabidae) and spiders (Araneae) in acidic coastal dunes at the southern Baltic Sea. Biol. Invasions 2011, 13, 605-620. [CrossRef]

143. Castro-Díez, P.; Gonzalez-Munoz, N.; Alonso, A.; Gallardo, A.; Poorter, L. Effects of exotic invasive trees on nitrogen cycling: A case study in Central Spain. Biol. Invasions 2009, 11, 1973-1986. [CrossRef]

144. Hejda, M.; Hanzelka, J.; Kadlec, T.; Štrobl, M.; Pyšek, P.; Reif, J. Impacts of an invasive tree across trophic levels: Species richness, community composition and resident species' traits. Divers. Distrib. 2017, 23, 997-1007. [CrossRef]

145. Reinhart, K.O.; Greene, E.; Callaway, R.M. Effects of Acer platanoides invasion on understory plant communities and tree regeneration in the northern Rocky Mountains. Ecography 2005, 28, 573-582. [CrossRef]

146. Simberloff, D.; Von Holle, B. Positive interactions of nonindigenous species: Invasional meltdown? Biol. Invasions 1999, 1, 21-32. [CrossRef] 
147. Von Holle, B.; Joseph, K.A.; Largay, E.F.; Lohnes, R.G. Facilitations between the introduced nitrogen-fixing tree, Robinia pseudoacacia, and nonnative plant species in the glacial outwash upland ecosystem of cape cod, MA. Biodivers. Conserv. 2006, 15, 2197-2215. [CrossRef]

148. Braga, R.R.; Gomez-Aparicio, L.; Heger, T.; Vitule, J.R.S.; Jeschke, J.M. Structuring evidence for invasional meltdown: Broad support but with biases and gaps. Biol. Invasions 2018, 20, 923-936. [CrossRef]

149. Pyšek, P.; Jarošik, V.; Hulme, P.E.; Pergl, J.; Hejda, M.; Schaffner, U.; Vilà, M. A global assessment of invasive plant impacts on resident species, communities and ecosystems: The interaction of impact measures, invading species' traits and environment. Glob. Chang. Biol. 2012, 18, 1725-1737. [CrossRef]

150. Bartz, R.; Kowarik, I. Assessing the environmental impacts of invasive alien plants: A review of assessment approaches. Neobiota 2019, 43, 69-99. [CrossRef]

151. Dyderski, M.K.; Jagodzinski, A.M. Drivers of invasive tree and shrub natural regeneration in temperate forests. Biol. Invasions 2018, 20, 2363-2379. [CrossRef]

152. Stohlgren, T.J.; Barnett, D.; Flather, C.; Fuller, P.; Peterjohn, B.; Kartesz, J.; Master, L.L. Species richness and patterns of invasion in plants, birds, and fishes in the United States. Biol. Invasions 2006, 8, 427-447. [CrossRef]

153. Stohlgren, T.J.; Barnett, D.T.; Kartesz, J. The rich get richer: Patterns of plant invasions in the United States. Front. Ecol. Environ. 2003, 1, 11-14. [CrossRef]

154. Fridley, J.D.; Stachowicz, J.J.; Naeem, S.; Sax, D.F.; Seabloom, E.W.; Smith, M.D.; Stohlgren, T.J.; Tilman, D.; Von Holle, B. The invasion paradox: Reconciling pattern and process in species invasions. Ecology 2007, 88, 3-17. [CrossRef]

155. Aronson, M.F.J.; La Sorte, F.A.; Nilon, C.H.; Katti, M.; Goddard, M.A.; Lepczyk, C.A.; Warren, P.S.; Williams, N.S.G.; Cilliers, S.; Clarkson, B.; et al. A global analysis of the impacts of urbanization on bird and plant diversity reveals key anthropogenic drivers. Proc. Biol. Sci. 2014, 281, 20133330. [CrossRef] [PubMed]

156. Ramirez-Cruz, G.A.; Solano-Zavaleta, I.; Mendoza-Hernandez, P.E.; Mendez-Janovitz, M.; Suarez-Rodriguez, M.; Zuniga-Vega, J.J. This town ain't big enough for both of us ... or is it? Spatial co-occurrence between exotic and native species in an urban reserve. PLoS ONE 2019, 14, e0211050. [CrossRef] [PubMed]

157. Matthews, E.R.; Schmit, J.P.; Campbell, J.P. Climbing vines and forest edges affect tree growth and mortality in temperate forests of the US Mid-Atlantic States. For. Ecol. Manag. 2016, 374, 166-173. [CrossRef]

158. Gaertner, M.; Larson, B.M.H.; Irlich, U.M.; Holmes, P.M.; Stafford, L.; van Wilgen, B.W.; Richardson, D.M. Managing invasive species in cities: A framework from Cape Town, South Africa. Landsc. Urban Plan. 2016, 151, 1-9. [CrossRef]

159. Sádlo, J.; Vitková, M.; Pergl, J.; Pyšek, P. Towards site-specific management of invasive alien trees based on the assessment of their impacts: The case of Robinia pseudoacacia. Neobiota 2017, 35, 1-34. [CrossRef]

160. Slabejová, D.; Bacigál, T.; Hegedüšová, K.; Májeková, J.; Medvecká, J.; Mikulová, K.; Šibíková, M.; Škodová, I.; Zaliberová, M.; Jarolímek, I. Comparison of the understory vegetation of native forests and adjacent Robinia pseudoacacia plantations in the Carpathian-Pannonian region. For. Ecol. Manag. 2019, 439, 28-40. [CrossRef]

161. Hanzelka, J.; Reif, J. Effects of vegetation structure on the diversity of breeding bird communities in forest stands of non-native black pine (Pinus nigra A.) and black locust (Robinia pseudoacacia L.) in the Czech Republic. For. Ecol. Manag. 2016, 379, 102-113. [CrossRef]

162. Morelli, F.; Benedetti, Y.; Su, T.P.; Zhou, B.; Moravec, D.; Šímová, P.; Liang, W. Taxonomic diversity, functional diversity and evolutionary uniqueness in bird communities of Beijing's urban parks: Effects of land use and vegetation structure. Urban For. Urban Green. 2017, 23, 84-92. [CrossRef]

163. Threlfall, C.G.; Mata, L.; Mackie, J.A.; Hahs, A.K.; Stork, N.E.; Williams, N.S.G.; Livesley, S.J. Increasing biodiversity in urban green spaces through simple vegetation interventions. J. Appl. Ecol. 2017, 54, 1874-1883. [CrossRef]

164. Kowarik, I. Einführung und Ausbreitung nichteinheimischer Gehölzarten in Berlin und Brandenburg und ihre Folgen für Flora und Vegetation. Ein Modell für die Freisetzung gentechnisch veränderter Organismen; Verhandlungen des Botanischen Vereins von Berlin und Brandenburg: Berlin, Germany, 1992; 188p.

165. Doroski, D.A.; Felson, A.J.; Bradford, M.A.; Ashton, M.P.; Oldfield, E.E.; Hallett, R.A.; Kuebbing, S.E. Factors driving natural regeneration beneath a planted urban forest. Urban For. Urban Green. 2018, 29, 238-247. [CrossRef]

166. Sukopp, H. Stadtökologie: Das Beispiel Berlin; D. Reimer: Berlin, Germany, 1990; 455p. 
167. Pickett, S.T.A.; Cadenasso, M.L.; Grove, J.M.; Nilon, C.H.; Pouyat, R.V.; Zipperer, W.C.; Costanza, R. Urban ecological systems: Linking terrestrial ecological, physical, and socioeconomic components of metropolitan areas. Annu. Rev. Ecol. Syst. 2001, 32, 127-157. [CrossRef]

168. Boring, L.R.; Swank, W.T. The Role of Black Locust (Robinia pseudoacacia) in Forest Succession. J. Ecol. 1984, 72, 749-766. [CrossRef]

169. Kowarik, I. Functions of clonal growth of trees in the wasteland-succession with special attention of Robinia pseudoacacia. Verh. d. Ges. f. Ökol. 1996, 26, 173-181.

170. Hobbs, R.J.; Higgs, E.S.; Hall, C. Novel Ecosystems: Intervening in the New Ecological World Order; Wiley-Blackwell: Hoboken, NJ, USA, 2013; 380p.

171. Lugo, A.E. Novel tropical forests: Nature's response to global change. Trop. Conserv. Sci. 2013, 6, 325-337. [CrossRef]

172. Shwartz, A.; Turbe, A.; Julliard, R.; Simon, L.; Prevot, A.C. Outstanding challenges for urban conservation research and action. Glob. Environ. Chang. 2014, 28, 39-49. [CrossRef]

173. Ives, C.D.; Lentini, P.E.; Threlfall, C.G.; Ikin, K.; Shanahan, D.F.; Garrard, G.E.; Bekessy, S.A.; Fuller, R.A.; Mumaw, L.; Rayner, L.; et al. Cities are hotspots for threatened species. Glob. Ecol. Biogeogr. 2016, 25, 117-126. [CrossRef]

174. Planchuelo, G.; von der Lippe, M.; Kowarik, I. Untangling the role of urban ecosystems as habitats for endangered plant species. Landsc. Urban Plan. 2019, 189, 320-334. [CrossRef]

175. Jarošík, V.; Konvička, M.; Pyšek, P.; Kadlec, T.; Beneš, J. Conservation in a city: Do the same principles apply to different taxa? Biol. Conserv. 2011, 144, 490-499. [CrossRef]

176. Jacquemyn, H.; Butaye, J.; Hermy, M. Forest plant species richness in small, fragmented mixed deciduous forest patches: The role of area, time and dispersal limitation. J. Biogeogr. 2001, 28, 801-812. [CrossRef]

177. Verheyen, K.; Hermy, M. The relative importance of dispersal limitation of vascular plants in secondary forest succession in Muizen Forest, Belgium. J. Ecol. 2001, 89, 829-840. [CrossRef]

178. Possingham, H.P.; Andelman, S.J.; Burgman, M.A.; Medellin, R.A.; Master, L.L.; Keith, D.A. Limits to the use of threatened species lists. Trends Ecol. Evol. 2002, 17, 503-507. [CrossRef]

179. Dearborn, D.C.; Kark, S. Motivations for Conserving Urban Biodiversity. Conserv. Biol. 2010, $24,432-440$. [CrossRef] [PubMed]

180. James, P.; Tzoulas, K.; Adams, M.D.; Barber, A.; Box, J.; Breuste, J.; Elmqvist, T.; Frith, M.; Gordon, C.; Greening, K.L.; et al. Towards an integrated understanding of green space in the European built environment. Urban For. Urban Green. 2009, 8, 65-75. [CrossRef]

181. Lepczyk, C.A.; Aronson, M.F.J.; Evans, K.L.; Goddard, M.A.; Lerman, S.B.; Macivor, J.S. Biodiversity in the City: Fundamental Questions for Understanding the Ecology of Urban Green Spaces for Biodiversity Conservation. Bioscience 2017, 67, 799-807. [CrossRef]

182. Pauleit, S.; Ambrose-Oji, B.; Andersson, E.; Anton, B.; Buijs, A.; Haase, D.; Elands, B.; Hansen, R.; Kowarik, I.; Kronenberg, J.; et al. Advancing urban green infrastructure in Europe: Outcomes and reflections from the GREEN SURGE project. Urban For. Urban Green. 2019, 40, 4-16. [CrossRef]

183. Buchholz, S.; Kowarik, I. Urbanisation modulates plant-pollinator interactions in invasive vs. native plant species. Sci. Rep. 2019, 9, 6375. [CrossRef] [PubMed]

184. Grimm, N.B.; Faeth, S.H.; Golubiewski, N.E.; Redman, C.L.; Wu, J.G.; Bai, X.M.; Briggs, J.M. Global change and the ecology of cities. Science 2008, 319, 756-760. [CrossRef] [PubMed]

185. Heger, T.; Bernard-Verdier, M.; Gessler, A.; Greenwood, A.D.; Grossart, H.-P.; Hilker, M.; Keinath, S.; Kowarik, I.; Kueffer, C.; Marquard, E.; et al. Towards an Integrative, Eco-Evolutionary Understanding of Ecological Novelty: Studying and Communicating Interlinked Effects of Global Change. Bioscience 2019, 69, 888-899. [CrossRef]

186. Soga, M.; Gaston, K.J. Extinction of experience: The loss of human-nature interactions. Front. Ecol. Environ. 2016, 14, 94-101. [CrossRef]

187. Soga, M.; Gaston, K.J.; Yamaura, Y.; Kurisu, K.; Hanaki, K. Both Direct and Vicarious Experiences of Nature Affect Children's Willingness to Conserve Biodiversity. Int. J. Environ. Res. Public Health 2016, 13, 529. [CrossRef] [PubMed]

188. Miller, J.R.; Hobbs, R.J. Conservation where people live and work. Conserv. Biol. 2002, 16, 330-337. [CrossRef] 
189. Schwarz, N.; Moretti, M.; Bugalho, M.N.; Davies, Z.G.; Haase, D.; Hack, J.; Hof, A.; Melero, Y.; Pett, T.J.; Knapp, S. Understanding biodiversity-ecosystem service relationships in urban areas: A comprehensive literature review. Ecosyst. Serv. 2017, 27, 161-171. [CrossRef]

190. Rupprecht, C.D.D.; Byrne, J.A. Informal urban greenspace: A typology and trilingual systematic review of its role for urban residents and trends in the literature. Urban For. Urban Green. 2014, 13, 597-611. [CrossRef]

191. Rupprecht, C.D.D.; Byrne, J.A.; Ueda, H.; Lo, A.Y. 'It's real, not fake like a park': Residents' perception and use of informal urban green-space in Brisbane, Australia and Sapporo, Japan. Landsc. Urban Plan. 2015, 143, 205-218. [CrossRef]

192. Threlfall, C.G.; Kendal, D. The distinct ecological and social roles that wild spaces play in urban ecosystems. Urban For. Urban Green. 2018, 29, 348-356. [CrossRef]

193. Riley, C.B.; Perry, K.I.; Ard, K.; Gardiner, M.M. Asset or Liability? Ecological and Sociological Tradeoffs of Urban Spontaneous Vegetation on Vacant Land in Shrinking Cities. Sustainability 2018, 10, 2139. [CrossRef]

194. Brun, M.; Di Pietro, F.; Bonthoux, S. Residents' perceptions and valuations of urban wastelands are influenced by vegetation structure. Urban For. Urban Green. 2018, 29, 393-403. [CrossRef]

195. Mathey, J.; Arndt, T.; Banse, J.; Rink, D. Public perception of spontaneous vegetation on brownfields in urban areas-Results from surveys in Dresden and Leipzig (Germany). Urban For. Urban Green. 2018, 29, 384-392. [CrossRef]

196. Maruthaveeran, S.; Konijnendijk van den Bosch, C.C. A socio-ecological exploration of fear of crime in urban green spaces-A systematic review. Urban For. Urban Green. 2014, 13, 1-18.

197. Nassauer, J.I. Messy Ecosystems, Orderly Frames. Landsc. J. 1995, 14, 161-170. [CrossRef]

198. Kühn, N. Intentions for the Unintentional: Spontaneous Vegetation as the Basis for Innovative Planting Design in Urban Areas. J. Landsc. Arch. 2006, 1, 46-53. [CrossRef]

199. Del Tredici, P. Spontaneous Urban Vegetation: Reflections of Change in a Globalized World. Nat. Cult. 2010, 5, 299-315. [CrossRef]

200. Hwang, Y.H.; Yue, Z.E.J. Intended wildness: Utilizing spontaneous growth for biodiverse green spaces in a tropical city. J. Landsc. Arch. 2019, 14, 54-63. [CrossRef]

201. Del Tredici, P.; Rueb, T. Other order: Sound walk for an urban wild. Arnoldia 2017, 75, 14-25. 